\title{
Aerosol cloud activation in summer and winter at puy-de-Dôme high altitude site in France
}

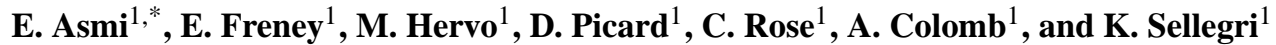 \\ ${ }^{1}$ Laboratoire de Météorologie Physique, UMR6016, Université Blaise Pascal, Clermont-Ferrand, France \\ *now at: Finnish Meteorological Institute, Erik Palménin aukio 1, 00560 Helsinki, Finland
}

Correspondence to: E. Asmi (eija.asmi@fmi.fi)

Received: 22 July 2012 - Published in Atmos. Chem. Phys. Discuss.: 6 September 2012

Revised: 19 November 2012 - Accepted: 20 November 2012 - Published: 4 December 2012

\begin{abstract}
Cloud condensation nuclei $(\mathrm{CCN})$ size distributions and numbers were measured for the first time at Puyde-Dôme high altitude (1465 m a.s.l) site in Central France. Majority of the measurements were done at constant supersaturation (SS) of $0.24 \%$, which was also deduced to be representative of the typical in-cloud SS at the site. CCN numbers during summer ranged from about 200 up to $2000 \mathrm{~cm}^{-3}$ and during winter from 50 up to $3000 \mathrm{~cm}^{-3}$. Variability of $\mathrm{CCN}$ number was explained by both particle chemistry and size distribution variability. The higher $\mathrm{CCN}$ concentrations were measured in continental, in contrast to marine, air masses. Aerosol CCN activity was described with a single hygroscopicity parameter $\kappa$. Range of this parameter was $0.29 \pm 0.13$ in summer and $0.43 \pm 0.19$ in winter. When calculated using SS of $0.51 \%$ during summer, $\kappa$ of $0.22 \pm 0.07$ was obtained. The decrease with increasing SS is likely explained by the particle size dependent chemistry with smaller particles containing higher amounts of freshly emitted organic species. Higher $\kappa$ values during winter were for the most part explained by the observed aged organics (analysed from organic $m / z 44$ ratio) rather than from aerosol organic to inorganic volume fraction. The obtained $\kappa$ values also fit well within the range of previously proposed global continental $\kappa$ of $0.27 \pm 0.21$. During winter, the smallest $\kappa$ values and the highest organic fractions were measured in marine air masses. CCN closure using bulk AMS chemistry led to positive bias of $5 \%$ and $2 \%$ in winter and summer, respectively. This is suspected to stem from size dependent aerosol organic fraction, which is underestimated by using AMS bulk mass composition. Finally, the results were combined with size distributions measured from interstitial and whole air inlets to obtain activated droplet size distributions. Cloud droplet
\end{abstract}

number concentrations were shown to increase with accumulation mode particle number, while the real in-cloud SS correspondingly decreased. These results provide evidence on the effects of aerosol particles on maximum cloud supersaturations. Further work with detailed characterisation of cloud properties is proposed in order to provide more quantitative estimates on aerosol effects on clouds.

\section{Introduction}

The global climate system is currently undergoing major changes due to the impacts of human actions (IPCC, 2007). The role of anthropogenic aerosols in this climate system is known to be important, though it remains inadequately defined. The aerosol interactions with clouds inflict several complex climatic modifications. Better understanding of the aerosol effects on clouds and of the aerosol-cloud interaction processes would largely improve the future climate predictions.

The ability of an aerosol particle to act as a cloud condensation nuclei (CCN) depends largely on its size and chemical composition (or water solubility). While in certain environments, the effect of size seems to largely surpass that of the particle chemistry (Ervens et al., 2005; Dusek et al., 2006; Koehler, 2006), several studies equally conclude on inevitable effects of particle composition and/or mixing state on their in-cloud activation (Roberts et al., 2002; Sellegri et al., 2003b; Ervens et al., 2005; Hudson, 2007; Cubison et al., 2008; Quinn et al., 2008; Kammermann et al., 2010; Ovadnevaite et al., 2011a). One of the ways to describe the size independent ability of aerosols to interact with water 
vapour is a simplified Köhler model (Köhler, 1936), called "kappa-Köhler", which relies on a single hygroscopicity parameter $\kappa$ as presented by Petters and Kreidenweis (2007). For insoluble aerosol, $\kappa$ becomes zero while for inorganic ammonium sulphate it is around 0.6 and for sodium chloride, around 1.2 (Petters and Kreidenweis, 2007).

Typical atmospheric $\kappa$-parameter values are around 0.1 to 0.4 for continental aerosol (Andreae and Rosenfeld, 2008; Gunthe et al., 2009, 2011; Chang et al., 2010; Pringle et al., 2010; Roberts et al., 2010; Fors et al., 2011; Kammermann et al., 2010; Bougiatioti et al., 2011; Cerully et al., 2011; Sihto et al., 2011) and 0.6 to 0.9 for marine aerosol (Allan et al., 2008; Hudson, 2007; Pringle et al., 2010). Pringle et al. (2010) recently suggested a range of continental aerosol $\kappa$ of $0.27 \pm 0.21$ and marine aerosol $\kappa$ of $0.72 \pm 0.24$. The variations in continental aerosol $\mathrm{CCN}$ activation properties are largely explained by the major fraction of aerosols being of organic origin (Saxena and Hildemann, 1996; Roberts et al., 2002; Zhang et al., 2007). While the activation properties of inorganic aerosols are relatively well quantified, those of the organics are yet largely uncertain. The aerosol organics affect aerosol cloud activation depending on their hygroscopic properties, further related with their origin and atmospheric lifetime (Ng et al., 2010; Raatikainen et al., 2010). Not only the gradual transformation towards more water soluble forms as subject to aging of the organics (Zhang et al., 2007; Jimenez et al., 2009; Raatikainen et al., 2010), but also the debated effects of organic surfactants or surface organic films (Gill et al., 1983; Lance et al., 2004; McFiggans et al., 2006) can cause significant variations to aerosol activation ability. Consequently, the efforts made in modelling the $\mathrm{CCN}$ based on chemical composition give variable results. Lance et al. (2009) obtained an overprediction of 3 to $36 \%$ of $\mathrm{CCN}$ from calculations of bulk chemical composition. Medina et al. (2007) could reduce a bias of $36 \%$ to about $17 \%$ by introducing a size-averaged chemical composition, and suggested the remaining discrepancy to be explained by the aerosol mixing state. Both of these studies assumed completely insoluble organic fraction. A vast number of studies have however found that a soluble fraction of organics with $\kappa$-parameter values between 0.1 to 0.3 is needed in order to explain the measured $\mathrm{CCN}$ concentrations with measured chemical composition (Bougiatioti et al., 2009; Chang et al., 2010; Roberts et al., 2010; Asa-Awuku et al., 2011; Bougiatioti et al., 2011; Cerully et al., 2011; Martin et al., 2011).

The number of cloud droplets further affects cloud properties, such as the cloud radiative forcing (Twomey, 1977) or cloud lifetime and precipitation patterns (Albrecht, 1989; Ramanathan et al., 2001; Rosenfeld et al., 2008). The aerosol impact is shown to be significant, and an increase of cloud droplet effective radius with decreasing aerosol concentration is shown by several studies (Henning et al., 2002; Ramanathan et al., 2001; Twohy, 2005; Lihavainen et al., 2008). It should be still kept in mind that the typically measured po- tential CCN numbers might not be directly proportional to the number of real activated cloud droplets (i.e. cloud droplet number concentration, CDNC). Next to the particle size and chemistry, which determine their CCN properties, CDNC is also dependent on external factors. The cloud supersaturation profile, which moreover depends on the updraft velocity, eventually determines the particle activation and further, the cloud climatic properties (Rogers, 1975). Constraints for the obtained supersaturation are formed by the amount of condensable water available, which the aerosols can also affect. In more precise terms, a higher initial aerosol concentration can decrease the water vapour mixing ratio and the release of latent heat with a consequence of smaller updraft and obtained cloud supersaturation (Planche et al., 2010). Thereby, this effect can, to some extent, counterbalance the effect of increasing aerosol concentration on cloud brightness (first indirect effect), and even more if the aerosol particles are highly water soluble. However, to our knowledge, this has not been verified by direct experimental evidence.

Within the current work, we examine three principal questions: (1) what is the range of measured $\mathrm{CCN}$ numbers during summer and winter seasons, (2) how do the particle cloud activation properties change with changing air masses, air chemistry, and environmental conditions, and finally, (3) are the $\mathrm{CCN}$ numbers measured representative for observed particle in-cloud activation and cloud droplet number concentrations? Within these themes, our specific goals are to obtain a closure between measured particle chemistry and CCN numbers as well as to indirectly determine the representative cloud supersaturations in each of the cloud events.

\section{Measurements and methods}

\subsection{Measurement site and campaigns}

Measurements were done at puy-de-Dôme (pdD) station $\left(45^{\circ} 46^{\prime} \mathrm{N} ; 2^{\circ} 57^{\prime} \mathrm{E}\right)$ in Central France (part of networks EMEP/GAW/ACTRIS). The station is on top of a mountain rising notably above the surrounding area with an altitude of $1465 \mathrm{~m}$ a.s.l. (Fig. 1). The nearest town, Clermont-Ferrand, is located $16 \mathrm{~km}$ east of the station at $396 \mathrm{~m}$ a.s.l. The surrounding area is largely characterized by forests and agricultural fields. More detailed description can be found in Venzac et al. (2009); Freney et al. (2011).

Size-segregated CCN measurements were done during three week campaigns both in summer and winter. Summer campaign took place between 24 June and 15 July 2011 and winter campaign between 24 January and 14 February 2012. Supporting in-situ measurements included aerosol chemistry derived with an AMS, total and interstitial aerosol size distributions measured using a SMPS, and various meteorological and gas phase measurements. Air mass back trajectories were calculated using Hysplit air transport model. During campaigns, variable conditions were observed with periods of 


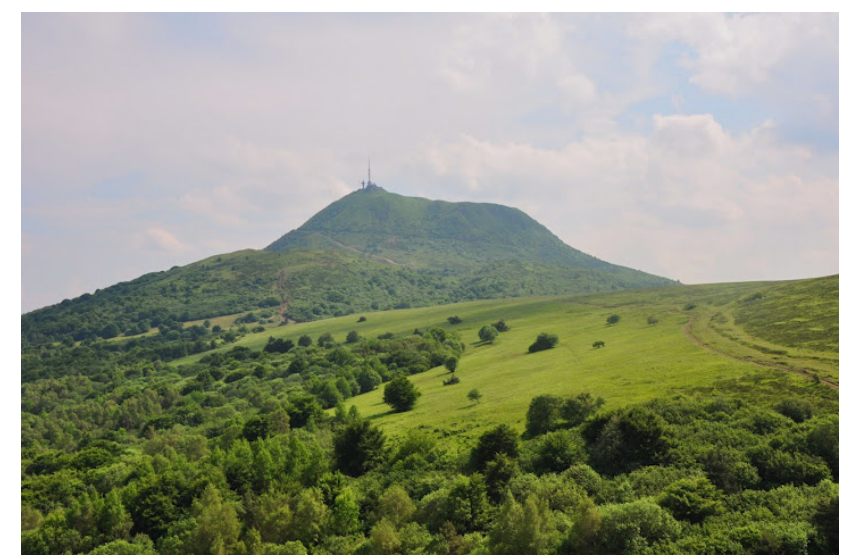

Fig. 1. Measurement site puy-de-Dôme.

continental and marine air masses, overall temperature range from -20 to $+20^{\circ} \mathrm{C}$, and the range of total number concentration extending between 100 and $10000 \mathrm{~cm}^{-3}$.

\subsubsection{CCNc measurements and calibrations}

Particle CCN activation properties as a function of size were measured using a miniature continuous-flow streamwise thermal-gradient $\mathrm{CCN}$ chamber $(\mathrm{CCNc})$ (Roberts and Nenes, 2005; Rose et al., 2008). The aerosol is introduced in the centreline of the growth column, and surrounded by filtered humidified sheath flow. Growth tube walls are continuously wetted and the obtained supersaturation is determined by the defined column temperature gradient (dT) and the flow rate. A total flow rate of $200 \mathrm{sccm}$ was used, with a sheath-to-aerosol flow ratio of 6 . The $\mathrm{CCN}$ numbers are detected with an optical detector in the end of the growth tube. During summer campaign, two temperature differences were used in CCNc: $6^{\circ} \mathrm{C}$ and $12^{\circ} \mathrm{C}$, which were measured in turns. During winter, to improve the time resolution, the $\mathrm{CCNc}$ was continuously run with $\mathrm{dT} 6^{\circ} \mathrm{C}$. Calibrations with ammonium sulphate and sodium chloride were used to determine the corresponding supersaturations (see below).

Before the CCNc, a TSI type DMA (length $44 \mathrm{~cm}$ ) was used to select the particle sizes. By stepping the voltage, sizes between 10 and $400 \mathrm{~nm}$ were measured within $15 \mathrm{~min}$ time period. A TSI CPC model 3010 was used after the DMA in parallel to $\mathrm{CCNc}$ for counting the total number of particles per size. Flow rate of $6.8 \mathrm{lpm}$ was used as a DMA sheath flow while a flow rate of $1.35 \mathrm{lpm}$ was used as a sample flow rate, comprising of the CPC flow $(1 \mathrm{lpm})$ and the $\mathrm{CCNc}$ flow $(0.35 \mathrm{lpm})$. The assembly of the system is thereafter called CCNc-DMPS. The aerosol was not dried before the DMA, but the inlet temperature and $\mathrm{RH}$ were continuously recorded to assure that the sample RH remained below $40 \%$.

Calibrations for the $\mathrm{CCN}$ counter were done every two weeks during both the summer and winter campaigns. Atomised solutions of sodium chloride and ammonium sulphate were used as calibration aerosols. In summer campaign, measurements were done using two temperature differences: 6 and $12{ }^{\circ} \mathrm{C}$. The calibration curves were corrected for doublycharged particles by removing a fraction determined with the height of the plateau in calibration curves (Rose et al., 2008). After this, sigmoidal fits were done separately for each of the curves of activated fraction as a function of particle diameter and the obtained activation diameters $\left(D_{\mathrm{p}_{50}}\right)$ were used to calculate the CCNc supersaturations. The obtained $D_{\mathrm{p}_{50}}$ values for ammonium sulphate and sodium chloride were $73.0 \pm 1.6 \mathrm{~nm}$ and $59.1 \pm 0.9 \mathrm{~nm}$, respectively, in winter at dT $6^{\circ} \mathrm{C}$. In summer, they were $75.4 \pm 0.1 \mathrm{~nm}$ and $60.1 \pm 0.6 \mathrm{~nm}$ at dT $6{ }^{\circ} \mathrm{C}$ while at dT $12{ }^{\circ} \mathrm{C}$ values of $45.3 \pm 1.5 \mathrm{~nm}$ and $35.4 \pm 0.2 \mathrm{~nm}$ were measured. First, the activation diameters were corrected for shape using factors 1.08 and 1.02 for sodium chloride and ammonium sulphate, respectively. Then, the corresponding $\mathrm{CCNc}$ supersaturation was calculated based on the Köhler theory (Köhler, 1936) as presented in Seinfeld and Pandis (1998)

$S_{c}=\exp \sqrt{\frac{256 M_{\mathrm{w}} \sigma_{\mathrm{w}}}{27 R T \rho_{\mathrm{w}}}\left(\frac{\rho_{\mathrm{w}}}{M_{\mathrm{w}}}\right)^{3}\left(\frac{\rho_{\mathrm{s}} i_{\mathrm{s}}}{M_{\mathrm{s}}}\right)^{-1} D_{\mathrm{p} 50}^{-3}}$

where $M_{\mathrm{w}}$ and $M_{\mathrm{s}}$ are the molecular weights of water $\left(0.018 \mathrm{~kg} \mathrm{~mol}^{-1}\right)$ and solute $\left(0.058 \mathrm{~kg} \mathrm{~mol}^{-1}\right.$ for $\mathrm{NaCl}$; $0.1321 \mathrm{~kg} \mathrm{~mol}^{-1}$ for $\left.\left(\mathrm{NH}_{4}\right)_{2} \mathrm{SO}_{4}\right), \rho_{\mathrm{W}}$ and $\rho_{\mathrm{s}}$ are the densities of water $\left(997 \mathrm{~kg} \mathrm{~m}^{-3}\right)$ and solute $\left(2165 \mathrm{~kg} \mathrm{~m}^{-3}\right.$ for $\mathrm{NaCl} ; 1770 \mathrm{~kg} \mathrm{~m}^{-3}$ for $\left.\left(\mathrm{NH}_{4}\right)_{2} \mathrm{SO}_{4}\right), R$ is the gas constant $\left(8.314 \mathrm{~J} \mathrm{~mol}^{-1} \mathrm{~K}^{-1}\right), T$ is the temperature $(298 \mathrm{~K}), \sigma_{\mathrm{w}}$ is the surface tension of water $\left(0.072 \mathrm{~J} \mathrm{~m}^{-2}\right), D_{\mathrm{p}_{50}}$ is the activation diameter and $i_{\mathrm{S}}$ is the van't Hoff factor (Young and Warren, 1992). The van't Hoff factor was estimated to be 2 for $\mathrm{NaCl}$ and 2.5 for $\left(\mathrm{NH}_{4}\right)_{2} \mathrm{SO}_{4}$, following the literature recommendations (e.g. Rose et al., 2008). In summer, the temperature difference of $6^{\circ} \mathrm{C}$ was deduced to correspond to a supersaturation (SS) of $0.234 \pm 0.001 \%(\min 0.233$; $\max 0.234)$ when using sodium chloride and $0.231 \pm 0.004 \%$ ( $\min 0.228$; max 0.236) when using ammonium sulphate. In winter, the corresponding values were $0.246 \pm 0.008 \%(\min 0.235$; $\max$ $0.255)$ and $0.237 \pm 0.005 \%(\min 0.232$; $\max 0.244)$. Additionally, the temperature difference of $12{ }^{\circ} \mathrm{C}$ in summer corresponded to a SS of $0.504 \pm 0.026 \%$ (min 0.486; $\max$ 0.544 ) when using ammonium sulphate and $0.512 \pm 0.005 \%$ (min 0.507; $\max 0.517$ ) when sodium chloride. Based on these, the $\mathrm{CCNc}$ supersaturations used could be estimated to be $0.24 \pm 0.01 \%\left(\mathrm{dT} 6{ }^{\circ} \mathrm{C}\right)$ and $0.51 \pm 0.01 \%\left(\mathrm{dT} 12^{\circ} \mathrm{C}\right)$. While the errors defined this way remain rather low, the errors caused by systematic biases, such as the estimates of van't Hoff factors, and errors caused by temperature deviations or simplifications in correcting for the multiply charged particles, should equally kept in mind. We made sensitivity studies using van't Hoff factor of \pm 0.2 around the preset values and $\pm 5^{\circ} \mathrm{C}$ deviation of temperature which led to standard deviation of supersaturation of roughly $0.02 \%$ and $0.01 \%$, respectively. In addition, due to higher quantity 
of doubly changed particles at higher supersaturations (as a result of the shape of atomised distributions) we estimated an additional $0.01 \%$ deviation at $\mathrm{dT} 12{ }^{\circ} \mathrm{C}$ following this. Therefore, we can more confidently use estimates of $0.24 \pm 0.02 \%$ (at $\mathrm{dT} 6{ }^{\circ} \mathrm{C}$ ) and $0.51 \pm 0.03 \%$ (at dT $12{ }^{\circ} \mathrm{C}$ ) as our effective $\mathrm{CCNc}$ supersaturations.

\subsubsection{Aerosol chemistry measurements}

An aerodyne cToF-AMS (Drewnick et al., 2005; Canagaratna et al., 2007) was used to measure the chemical composition and mass concentration of the non-refractory submicron particulate matter (NR-PM1). Using the standard fragmentation table described by Allan et al. (2004), chemically resolved mass concentrations of individual species were extracted from the raw cToF-AMS data. Adjustments to the fragmentation table were made based on particle free measurement periods. The resolved mass concentrations include ammonium, sulphate, nitrate, organic, and chloride species.

In order to calculate quantitative mass concentrations from the cToF-AMS it is necessary to calculate the collection efficiency (CE) of the cToF-AMS. The cToF-AMS does not sample all particles with the same efficiency, and for example non-spherical particles are not always focused into the particle beam. Similarly particles can sometimes bounce away from the heated filament of the cToF-AMS. In order to correct for these sampling artifacts, a collection efficiency factor is applied to the raw cToF-AMS data. Optimisation of this $\mathrm{CE}$ is achieved through comparison with other aerosol measurements. The CE normally varies between 0.5 and 1 (Middlebrook et al., 2012). Middlebrook et al. (2012) demonstrated that particles containing high ammonium nitrate concentrations are more efficiently sampled by the AMS than other inorganic and organic species. Similar to Freney et al. (2011), a composition dependent CE is applied to the data:

$\mathrm{CE}_{\mathrm{DRY}}=\max (0.5,0.264+0.943 \mathrm{ANMF})$

where a constant $\mathrm{CE}$ of 0.5 is used for ANMF $\leq 0.25$ and a linear CE increase up to 1 for ANMF $>0.25$ (Freney et al., 2011). The accuracy of the chosen CE was confirmed through comparison with a scanning mobility particle sizer (SMPS), where the total volume of aerosol particles sampled by the AMS (together with black carbon, BC, measured using a MAAP) was compared with that sampled by a SMPS. The AMS volume was calculated by dividing the mass concentrations of organic and inorganic species by their respective densities. A CE of 0.5 was used for both the summer and winter experiments. Comparison of the SMPS and cToFAMS volume concentration resulted in a slope of 0.76 and 0.64 , and a $R^{2}$ of $77 \%$ and $83 \%$ for the summer and winter experiments, respectively.

Aerosol particles were sampled through either a whole air inlet (WAI, $50 \%$ cut-off size of $30 \mu \mathrm{m}$ ) or an interstitial inlet (INT, $50 \%$ cut-off size of $5 \mu \mathrm{m}$ ) during the experiment and then passed through a $72-\mathrm{cm}$-long diffusion dryer. Filter measurements were performed at least once daily. The cToF-AMS was calibrated for size distribution measurements using polystyrene latex spheres with sizes ranging from $80 \mathrm{~nm}$ up to $400 \mathrm{~nm}$. Ionisation efficiency calibrations were performed using $\mathrm{NH}_{4} \mathrm{NO}_{3}$ particles. $\mathrm{NH}_{4} \mathrm{NO}_{3}$ particles were atomised through a dryer and a range of sizes were selected using a differential mobility analyser $(200 \mathrm{~nm}$ to $400 \mathrm{~nm}$ ) prior to being measured by the cToF-AMS. Ionization efficiencies ranged from $6.08 \times 10^{-8}$ (June 2011) to $1.955 \times 10^{-7}$ (January 2012).

\subsubsection{Inlet system and auxiliary measurements}

The auxiliary measurements, which were used to explain the observed CCN features, included particle chemical composition and number size distribution, as well as numerous meteorological parameters. Most of the instruments were operated behind the WAI, but the number size distribution was measured in turns using both the WAI and INT. The total flow rates of the inlets were kept constant so that the $50 \%$ cut-off size of the WAI inlet was $30 \mu \mathrm{m}$ while that of the INT was $5 \mu \mathrm{m}$. However, at high wind speeds it is possible that the largest droplets are not efficiently collected on top of the inlet, and the provided in-cloud number concentrations should therefore be considered as lower estimates.

The aerosol size distribution was measured using a SMPS operated in a size range from 10 to $500 \mathrm{~nm}$. Correct sizing of both CCNc-DMPS and SMPS systems was verified with $100 \mathrm{~nm}$ atomised latex particles, and with regular checks of flow rates and DMA voltages. The results of the two independent systems compared well. Details of the SMPS system used can be found in Venzac et al. (2009). The SMPS system collected particles from both WAI and INT, and the inlet line was switched by an automated valve system every $15 \mathrm{~min}$. Line length was $1.5 \mathrm{~m}$ in both WAI and INT.

The BC mass concentration was measured using a Multi Angle Absorption Photometer (MAAP 5012). Meteorological parameters (including wind direction, wind speed, relatively humidity $\mathrm{RH}$, pressure, and temperature) were also measured at the site continuously.

\subsection{Analysis}

\subsubsection{Correction for doubly-charged particles}

One of the goals by using size-resolved CCN measurements is to understand to what extent the particle activation can be characterized by a single activation diameter, $D_{\mathrm{p}_{50}}$, and to which extent the atmospheric particles are an external mixture with varying amount of particles having different properties of activation. Since doubly-charged particles can falsely broaden the activation D-curve (activated fraction as a function of particle size), we used the size distribution data, measured in parallel, in order to correct for this broadening. The procedure was as follows: 
1. Inverted CCNc-DMPS size distributions were normalized by channel widths to get $\Delta N / \Delta D_{\mathrm{p}}$ distributions. By this normalization, the obtained $\Delta N / \Delta D_{\mathrm{p}}$ values, thereafter called $\mathrm{N}_{i}$, in channels $i$, could be directly inter-compared.

2. For each particle size, $D_{\mathrm{p}_{i}}$, a corresponding size of doubly-charged particles, $D_{\mathrm{p}_{\mathrm{j}}}$, was calculated and a fraction of doubly-charged particles, $f_{j}$, at this new size vector was determined using bipolar steady-state assumption as given by Wiedensohler (1989). $\mathrm{N}_{j 2 \mathrm{e}}$ values, i.e. the normalized number concentrations of doublycharged particles at sizes $D_{\mathrm{p}_{j}}$ could then be determined as $f_{j} \cdot \mathbf{N}_{j}$, where the values of $\mathbf{N}_{j}$ were obtained from $\mathrm{N}_{i}$ by interpolation.

3. Fraction of doubly-charged particles measured at each $D_{\mathrm{p}_{i}}$ was further calculated as $f_{i}=\mathrm{N}_{j 2 \mathrm{e}} /\left(\mathrm{N}_{j 2 \mathrm{e}}+\mathrm{N}_{i 1 \mathrm{e}}\right)$. $\mathrm{N}_{i 1}$ e here is the singly-charged normalized concentration in selected channel $i$ calculated according to Wiedensohler (1989). This way, the number of doublycharged particles was compared to the total number of charged particles measured in channel $i$, which is then the sum of singly-charged and doubly-charged particles.

4. Activated fraction, $\mathrm{Af}_{i}$, was calculated for each measured diameter (channel) as $\mathrm{CCN}_{i} / \mathrm{CN}_{i}$, and again interpolated to size vector of doubly-charged particles.

5. Beginning from the largest diameters, new activated fractions accounting only for the singly-charged particles were calculated. The doubly-charged particles were subtracted from $\mathrm{CN}$ numbers to get singly-charged number concentrations as $\mathrm{CN}_{i 1 \mathrm{e}}=\mathrm{CN}_{i}-f_{i} \cdot \mathrm{CN}_{i}$. Similarly, however taking into account also the activated fraction in the doubly-charged sizes $\left(\mathrm{Af}_{j}\right)$, the doublycharged particles were subtracted from $\mathrm{CCN}$ numbers as $\mathrm{CCN}_{i 1 \mathrm{e}}=\mathrm{CCN}_{i}-f_{i} \cdot \mathrm{CN}_{i} \cdot \mathrm{Af}_{j}$. New $\mathrm{Af}_{j}$ was calculated by interpolating from $\mathrm{CCN}_{i 1 \mathrm{e}} / \mathrm{CN}_{i 1 \mathrm{e}}$, which could be used again to resolve the corrected activated fractions in smaller sizes.

\subsubsection{Sigmoidal fitting and parameters characterizing CCN activation}

After the corrections, a sigmoidal function

$$
\frac{\mathrm{N}_{\mathrm{CCN}}}{\mathrm{N}_{\mathrm{CN}}}=\frac{E}{1+\left(\frac{D_{\mathrm{p} 50}}{D_{\mathrm{p}}}\right)^{c^{*}}}
$$

was fitted to activated fraction as a function of particle diameter, $D_{\mathrm{p}}$. The fitting parameters represent the critical activation diameter, $D_{\mathrm{p}_{50}}$, the height of the activation curve, $E$, and its steepness, $c^{*}$. The value of $c^{*}$ can now be used as a measure of homogeneity of the aerosol mixture, i.e. the higher the value of $c^{*}$, the more internally mixed the particles are (the activation D-curve is steeper). However, as the mobility channels in DMA are not equal in width, a correction for transfer function broadening is needed to make the values of $c^{*}$ independent of activation size. This was done using the method proposed by Rose et al. (2008). The aerosol distribution function was obtained by linear interpolation of the measured aerosol size distribution $\left(\Delta N / \Delta D_{\mathrm{p}}\right)$ and normalized to one. Transfer function was assumed to have an ideal triangular shape and a full-width determined by the aerosolto-sheath flow ratio 1/5. Measured size was corrected by integrating the aerosol distribution function over the transfer function range until a measured activated fraction was obtained.

\subsubsection{Kappa-Köhler model}

The CCN activity of aerosol particles can be described using "kappa-Köhler" model (Petters and Kreidenweis, 2007). The saturation ratio, $S$, over the droplet surface

$S\left(D_{\mathrm{p}}\right)=\frac{D_{\mathrm{p}}^{3}-D_{\mathrm{p} 50}^{3}}{D_{\mathrm{p}}^{3}-D_{\mathrm{p} 50}^{3}(1-\kappa)} \exp \left(\frac{4 \sigma_{\mathrm{w}} M_{\mathrm{w}}}{R T \rho_{\mathrm{w}} D_{\mathrm{p}}}\right)$

can be used to find the kappa $\kappa$, corresponding to measured critical activation diameter $D_{\mathrm{p}_{50}}$. Kappa values were determined by numerical iteration varying $\kappa$ until the maximum of the saturation curve was equal to the saturation used inside the CCNc. Surface tension $\rho_{\mathrm{w}}$ was approximated using the surface tension of water. The value of $\kappa$ represents the hygroscopicity of an ideally mixed aerosol, to which the Zdanovskii, Stokes, and Robinson (ZSR) mixing rule (Stokes and Robinson, 1966) applies. Using this equation to our calibration aerosol leads to kappa values of $1.2 \pm 0.1$ and $0.6 \pm 0.1$ for sodium chloride and ammonium sulphate, respectively, considering the observed variations in activation diameter and those in supersaturation estimation.

\subsubsection{Air mass back trajectory calculations}

Air mass backward trajectories for the arrival pressure level of $850 \mathrm{hPa}$ were calculated using Hysplit model (Draxler and Hess, 1998). Trajectories were calculated every three hours, the first starting at 00:00 UTC time $(-1 \mathrm{~h}$ local winter time). Air masses were followed $72 \mathrm{~h}$ backwards in onehour time steps. Based on determined back trajectories, the air masses were divided into continental, mediterranean, marine and marine modified types (sectors: $10-130^{\circ}, 130-260^{\circ}$, $260-315^{\circ}$ and $315-10^{\circ}$, respectively), according to the maximum of time spent per sector. The classification is identical to that previously used by Freney et al. (2011). In addition to these sectors, air masses circulating mainly above continental France were classified as local. 


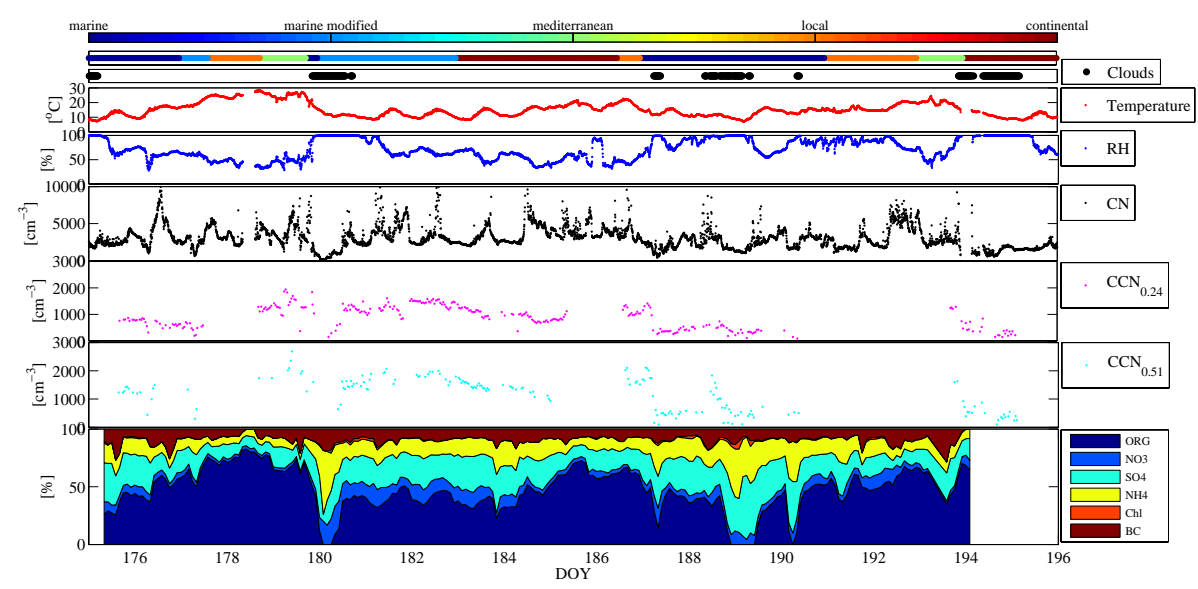

Fig. 2. Overview of conditions during the summer campaign. On panels, from top to down, are shown: air mass type, station inside cloud periods, temperature, relative humidity, total number concentration, $\mathrm{CCN}$ number concentration (at 0.24 and $0.51 \%$ supersaturations) and AMS volume fractions.

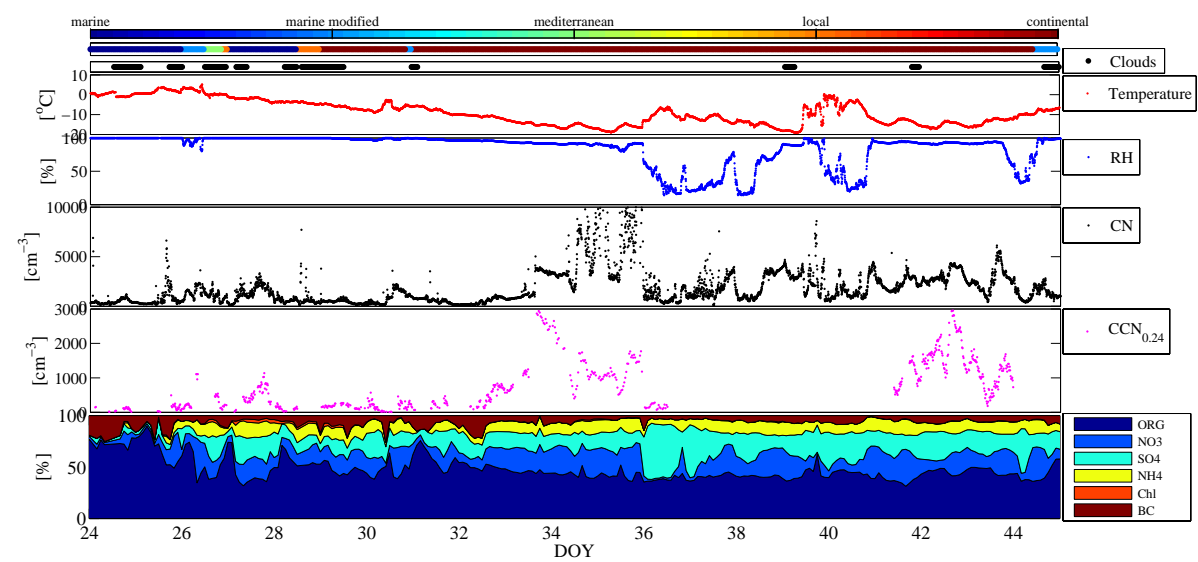

Fig. 3. Overview of conditions during the winter campaign. On panels, from top to down, are shown: air mass type, station inside cloud periods, temperature, relative humidity, total number concentration, $\mathrm{CCN}$ number concentration (at $0.24 \%$ supersaturation) and AMS volume fractions.

\section{Results}

\subsection{CCN number concentration in summer and winter}

General overviews of summer and winter campaign meteorological conditions along with the measured $\mathrm{CN}$ and $\mathrm{CCN}$ concentrations are presented in Figs. 2 and 3. Temperature in summer varied between 10 and $30^{\circ} \mathrm{C}$, and relative humidity (RH) between 45 and $100 \%$. Marine and modified marine air masses were prevailing during the summer campaign, but also all other air mass types were detected. The total number concentration ranged from some hundreds up to 10000 particles $\mathrm{cm}^{-3}$ while the measured $\mathrm{CCN}$ concentrations were typically between 200 and $2000 \mathrm{~cm}^{-3}$. Three major periods of in-cloud measurements were captured.

The mass concentrations of sulphate and nitrate aerosol composition in summer were low with similar trends and variability (Fig. 2). Organic aerosol particles contributed be- tween $50 \%$ and $80 \%$ to the aerosol volume fraction with highest concentrations measured at the start of the campaign and were dependent on air mass origin and meteorological situation. With increasing temperature, the organic aerosol composition increased gradually with time, as can be observed during the first part of the experiment. The arrival of clouds and rainfall events resulted in a sudden decrease in the organic particle mass concentration.

During the winter campaign, continental air masses prevailed for most of the time after a short period of marine air in the beginning. Very cold temperatures in the range from $-20^{\circ} \mathrm{C}$ up to around $0{ }^{\circ} \mathrm{C}$ were detected. During the first half of the campaign, many in-cloud periods were captured. The first half was characterised with high RH conditions, and clean air with only some tens or hundreds of particles and CCNs. After this, a dryer continental period with increased $\mathrm{CN}$ and $\mathrm{CCN}$ concentrations prevailed for the rest of the 

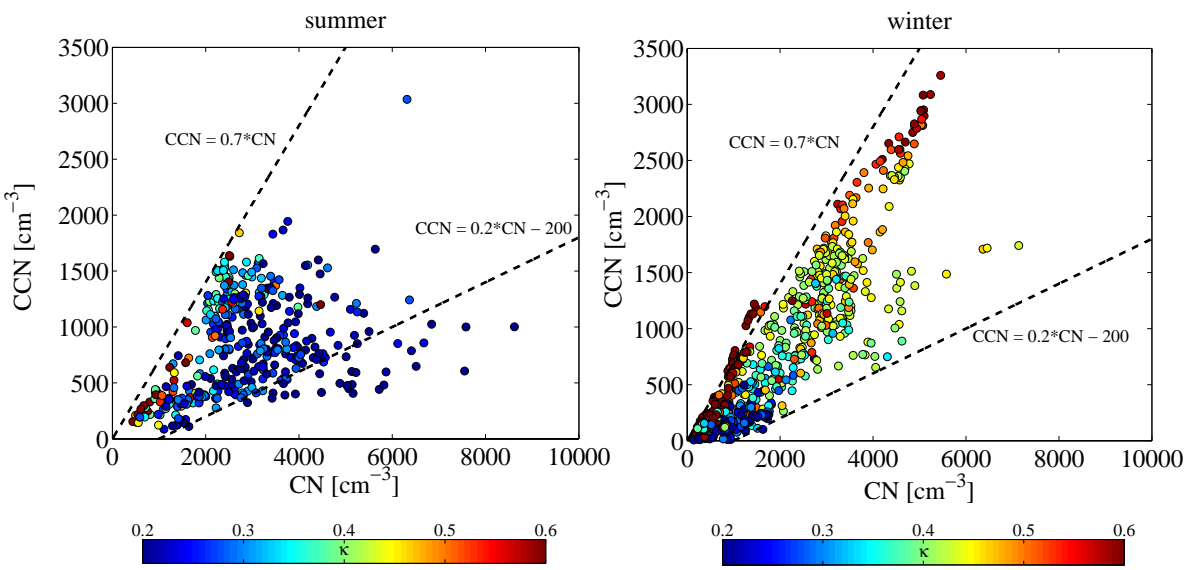

Fig. 4. $\mathrm{CCN}_{0.24}$ concentration as a function of the total particle number concentration $(\mathrm{CN})$ separately for summer (left) and winter (right). Colour shows the hygroscopicity parameter $\kappa$ value with scale ranging from 0.2 to 0.6 . Dashed linear lines show the visually defined boundaries in within most of the data are centered.

summer

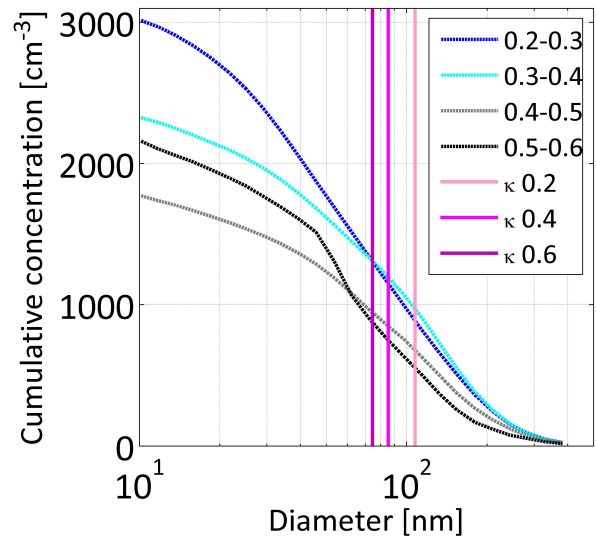

winter

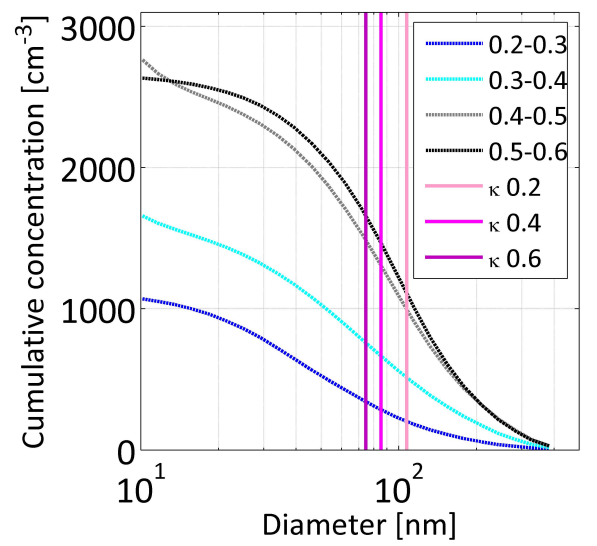

Fig. 5. Selected cumulative number size distribution measured during summer (left) and winter (right) when the total aerosol $\kappa$ value ranged from 0.2 to 0.3 (blue dashed line), from 0.3 to 0.4 (light blue dashed line), from 0.4 to 0.5 (grey dashed line) and from 0.5 to 0.6 (black dashed line). The horizontal lines depicted mark the corresponding CCN activation diameter for $\kappa$ values of $0.2,0.4$ and 0.6 (assuming SS of $0.24 \%)$.

campaign. CCN concentrations increased up to $3000 \mathrm{~cm}^{-3}$ and total number up to $10000 \mathrm{~cm}^{-3}$.

During the winter campaign aerosol composition was variable with inorganic species contributing high volume fractions $(65 \% \pm 17 \%)$ to the submicron aerosols mass (Fig. 3). The fraction of the organic aerosol varied between $20 \%$ and $77 \%$, with an average contribution of $36 \% \pm 7 \%$. The AMS mass spectra indicated strong influences from biomass burning events from 5 February to 15 February with increases in $\mathrm{NO}_{3}$ mass fractions up to $70 \%$. A more detailed discussion on the submicron aerosol mass concentration sampled by the cToF-AMS during these winter and summer measurements is provided in Freney et al. (2012).

The connection between total particle number and $\mathrm{CCN}_{0.24}$ number (measured at SS $0.24 \%$ ) is shown in Fig. 4. Part of the variability in $\mathrm{CCN}$ to total $\mathrm{CN}$ ratio can be ex- plained by the variations in aerosol modal characteristics (Fig. 5). During winter, periods of long-range transported polluted continental aerosol were common, with characteristics of strong accumulation mode. The most elevated $\kappa$ values were also measured in polluted air masses. Correspondingly, higher $\mathrm{CCN}$ to $\mathrm{CN}$ fractions, as well as higher $\kappa$ values were measured in winter. An increase of $\kappa$ values could indicate a higher fraction of long-range transported aged organics, as shown by Raatikainen et al. (2010), or simply a lower fraction of organics in comparison to aerosol inorganic, and typically more hygroscopic, fraction. Additionally, during winter the measurement site is occasionally above the boundary layer air mixing height, when more aged free tropospheric aerosol can be measured (e.g. Venzac et al., 2009). In contrast, during summer, a major fraction of the total particle number consisted of particles of sizes below $100 \mathrm{~nm}$ (Fig. 5) 
and correspondingly, the $\mathrm{CCN}$ to $\mathrm{CN}$ fraction occasionally decreased. In contrast to the winter season, no clear coupling between $\kappa$ and particle number concentration was seen in summer (Fig. 5). This suggests that changes in aerosol chemistry and therefore in $\kappa$ were important for the observed variability in $\mathrm{CCN}$ to $\mathrm{CN}$ fraction. During both summer and winter, the maximum $\mathrm{CCN}_{0.24}$ concentration was about $70 \%$ of the total aerosol concentration (Fig. 4). This high fraction of CCNs was detected when the aerosol hygroscopicity parameter $\kappa$ reached its most elevated values of $>0.5$. CCN to $\mathrm{CN}$ fraction showed more scatter during summer than winter, and especially when the $\kappa$ was small. A linear fit to $\mathrm{CCN}$ versus $\mathrm{CN}$ resulted expectedly in better correlation during winter: a slope of 0.47 was obtained $\left(R^{2}=0.80\right)$ in contrast to summer, when the slope was $0.13\left(R^{2}=0.15\right)$.

\subsection{Hygroscopicity parameter $\kappa$}

To further examine the aerosol CCN activation properties, sigmoidal fittings were done for the size-segregated activated fractions (Eq. 3). The activation diameters $\left(D_{\mathrm{p}_{50}}\right)$ for summer and winter were obtained using Eq. (3). This led to values of $95 \pm 12 \mathrm{~nm}$ and $86 \pm 13 \mathrm{~nm}$ for summer and winter, respectively, at SS $0.24 \%$. In addition, during summer the measurements in SS $0.51 \%$ gave an activation diameter value of $65 \pm 7 \mathrm{~nm}$.

By using the $\kappa$-Köhler model (Eq. 4), aerosol $\kappa$ values were determined. The overall average $\kappa$ (calculated at SS $0.24 \%$ ) during summer was $0.29 \pm 0.13$ (median 0.26 ). This fits well to the suggested global average aerosol $\kappa$ of around 0.3 measured in continental sites (Andreae and Rosenfeld, 2008; Pringle et al., 2010). The $\kappa$ calculated at SS $0.51 \%$ was however lower, being $0.22 \pm 0.07$ (median 0.20). In contrast, during winter the $\kappa$ value of $0.43 \pm 0.19$ (median 0.42) was obtained, despite the fact that the aerosol was mainly of continental origin with a significant fraction of organics included (see the next subsection). While a $\kappa$ value of 0.43 fits within the suggested range of $0.27 \pm 0.21$ (Pringle et al., 2010 ), in previous studies $\kappa$ on the same order have mainly been observed for sulphate enriched aerosol of moderate organic fraction (Kuwata et al., 2008; Mochida et al., 2010), unlike here.

\subsection{Aerosol CCN properties by air masses}

As already implied by our coarse classification of air masses, the aerosol CCN properties manifest significant variations with air mass origin. We examined the effect of air mass origin to our on-site measured aerosol CCN properties by following the air mass route three days backwards, and starting a new trajectory every three hours. The nearby region was divided into equal sized squares $\left(5^{\circ} \times 3^{\circ}\right.$ in summer and $8^{\circ} \times 3^{\circ}$ in winter). In summer the air masses came from smaller geographical area which enabled us to use a better resolution grid size with approximately the same statistics
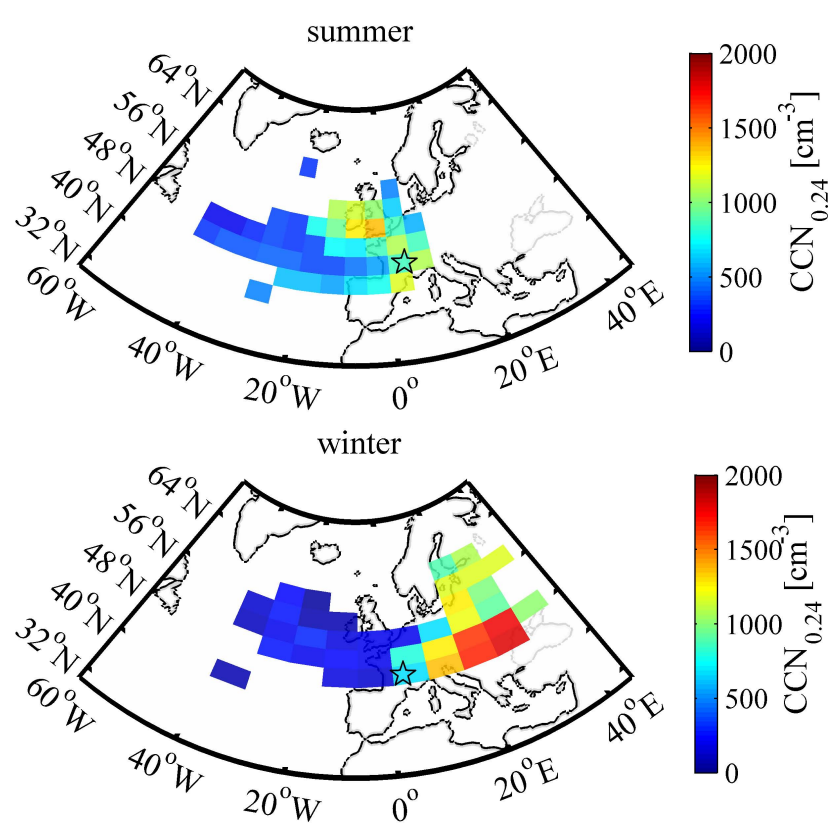

Fig. 6. $\mathrm{CCN}_{0.24}$ concentrations with the air mass origin during summer (up) and winter (down). The star marks the location of the measurement site. For details of the calculations, see Sect. 3.3: aerosol $\mathrm{CCN}$ properties by air masses.

per square. The impact of aerosol in each square on the measured aerosol was weighted by the time the air mass spent in the square as well as by the temporal distance to the end trajectory point (measurement site). The trajectory points determined 3-days ago were weighted by $50 \%$ and the weight increased linearly with time up to $100 \%$ at the closest trajectory point. This way, the measurements at pdD site were thought to be the most representative to the squares (regions) where air mass had passed lately and/or where the air mass had spent most of its time. To calculate averages of different measured quantities for each square, minimum of three values, each representing average of $3 \mathrm{~h}$ of measurements, was required. In practise, if for example air masses had passed via a specific region (square) five times all together during the campaign but on different days, we assumed that the impact of this region was reflected to our on-site measured aerosol quantities (such as the $\mathrm{CCN}$ concentration or aerosol kappa). Depending on the temporal distance between the region and the measurement site, and the time the air mass spent on that region, a weight was given for each of the five individual measurements and average of them was calculated.

During both summer and winter, the continental air masses resulted in highest CCN concentrations (Fig. 6). During winter, very high $\mathrm{CCN}$ concentrations (average $>1500 \mathrm{~cm}^{-3}$ ) were seen in air masses originating from Eastern Europe and moderately elevated $\mathrm{CCN}$ concentrations (around $1000 \mathrm{~cm}^{-3}$ ) in air masses from Northern and Central Europe. For the summer experiment, the highest $\mathrm{CCN}$ concentrations (around $1000 \mathrm{~cm}^{-3}$ ) were detected in air masses originating 

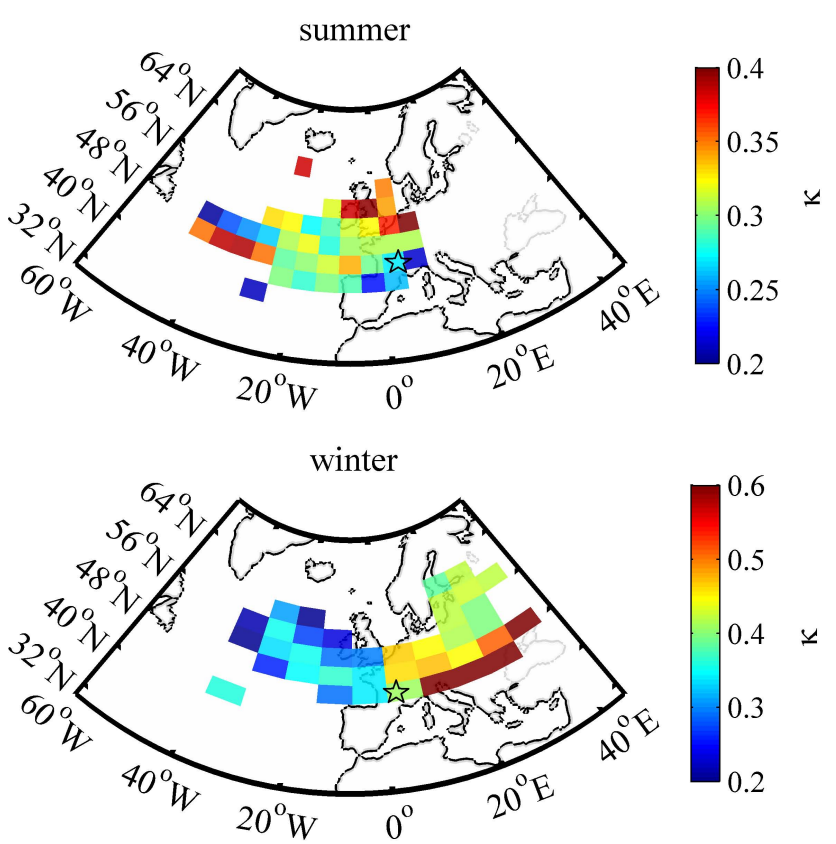

Fig. 7. Hygroscopicity parameter $\kappa$ value with the air mass origin during summer (up) and winter (down). The star marks the location of the measurement site. For details of the calculations, see Sect. 3.3: aerosol CCN properties by air masses. Note that the colour scale is different for summer and winter.

from British Isles and Central Europe, while air masses from Eastern Europe were not measured during the campaign. The $\mathrm{CCN}$ concentrations in marine air masses during both seasons were typically well below $500 \mathrm{~cm}^{-3}$, but average values of around or even above $500 \mathrm{~cm}^{-3}$ were occasionally detected.

The aerosol hygroscopicity parameter $\kappa$ showed interesting variations with respect to the air mass origin (Fig. 7). During summer, the $\kappa$ value reached its minimum of $<0.2$ in Southern European air masses, but low values of $\kappa$ were also seen in marine air masses. However, $\kappa$ in marine air masses seemed highly dispersed, with variation of values between 0.2 and 0.4. The Northern European air masses further showed the highest $\kappa$ values of around 0.4. The overall variation of $\kappa$ during summer was less pronounced in comparison to winter. The $\kappa$ in winter presented clear differences between the air masses, with lowest values of around 0.2 detected in marine air masses, and highest of $>0.6$ in Southern European air masses. This is slightly counterintuitive, because marine aerosols are generally seen to be highly hygroscopic and the polluted continental aerosols less hygroscopic (e.g. Pringle et al., 2010).

The total $\mathrm{CCN}$ to $\mathrm{CN}$ ratio was generally higher in continental in comparison to marine air, and the lowest ratios of around 0.2 are seen in marine air masses for both summer and winter (Fig. 8). While this is contradictory to Roberts et al. (2010), who measured average $\mathrm{CCN}$ to $\mathrm{CN}$ ratios of
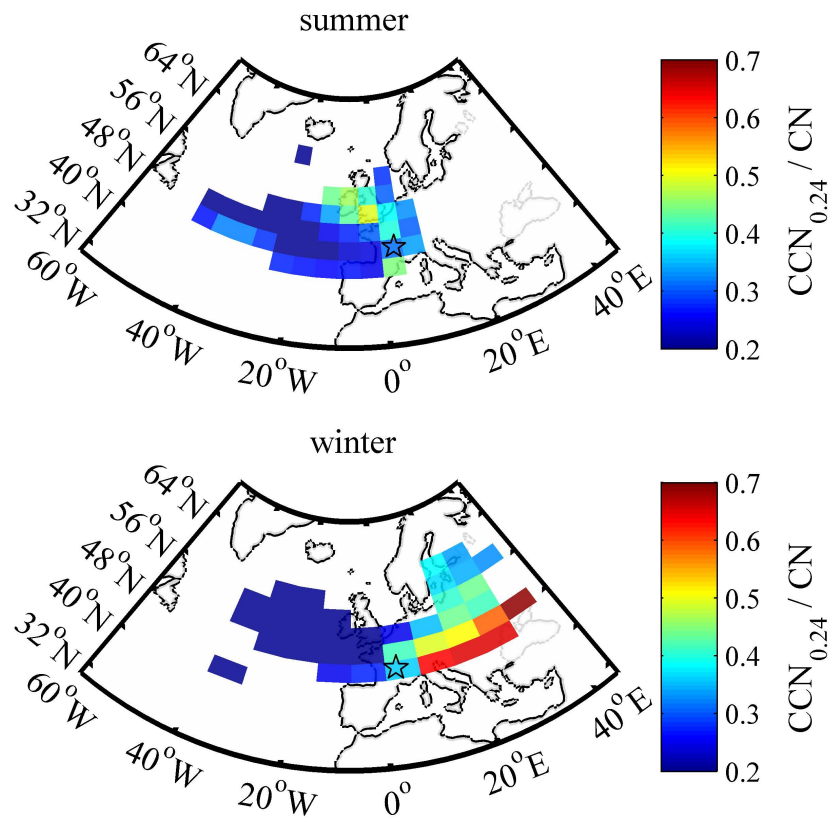

Fig. 8. $\mathrm{CCN}_{0.24}$ to total $\mathrm{CN}$ ratios with the air mass origin during summer (up) and winter (down). The star marks the location of the measurement site. For details of the calculations, see Sect. 3.3: aerosol CCN properties by air masses.

0.6, 0.26 and 0.09 for free tropospheric, marine and continental aerosol, respectively, the aerosol modal characteristics explain part of the descrepancy (Fig. 5). The continental aerosol at our site seems much more aged, and in lack of near-by pollution sources, the nucleation and Aitken mode concentrations remain moderate. In contrast, the fraction of $0.26 \pm 0.21$ suggested by Roberts et al. (2010) for marine aerosol, fits well in our dataset as well. Overall, however, our results seem to suggest that the $\mathrm{CCN}$ to $\mathrm{CN}$ ratio is highly variable between different sites and measurement conditions. For example, Gunthe et al. (2009) found a ratio CCN to $\mathrm{CN}$ of around 0.48 (at SS $0.28 \%$ ) as measured in tropical rainforest when average aerosol $\kappa$ was 0.15 . Sihto et al. (2011) found a $\mathrm{CCN}$ to $\mathrm{CN}$ value of around 0.2 (at SS $0.2 \%$ ) in boreal forest, when the value of aerosol $\kappa$ was 0.18 and the aerosol chemical composition was controlled by organics. On other side, Ovadnevaite et al. (2011a) measured $\mathrm{CCN}$ to $\mathrm{CN}$ ratios of $>0.8$ for marine aerosol enriched with primary organics, while lower ratios of around 0.5 were obtained when aerosol was enriched with sulphates. Interestingly, for each different air mass, the $\mathrm{CCN}$ to $\mathrm{CN}$ ratios follow closely the variations in total CCN number concentration (Fig. 6). Furthermore, especially in winter, this follows the variations in $\kappa$ (Fig. 7).

The organic mass fractions measured by the cToF-AMS give further support to our CCN results (Fig. 9). Indeed, it seems the marine air masses contained a notable fraction of organics during winter. This is also what was found by Sellegri et al. (2003a) at the pdD site. Unfortunately, the latest results of aerosol chemical composition seasonal variation by 

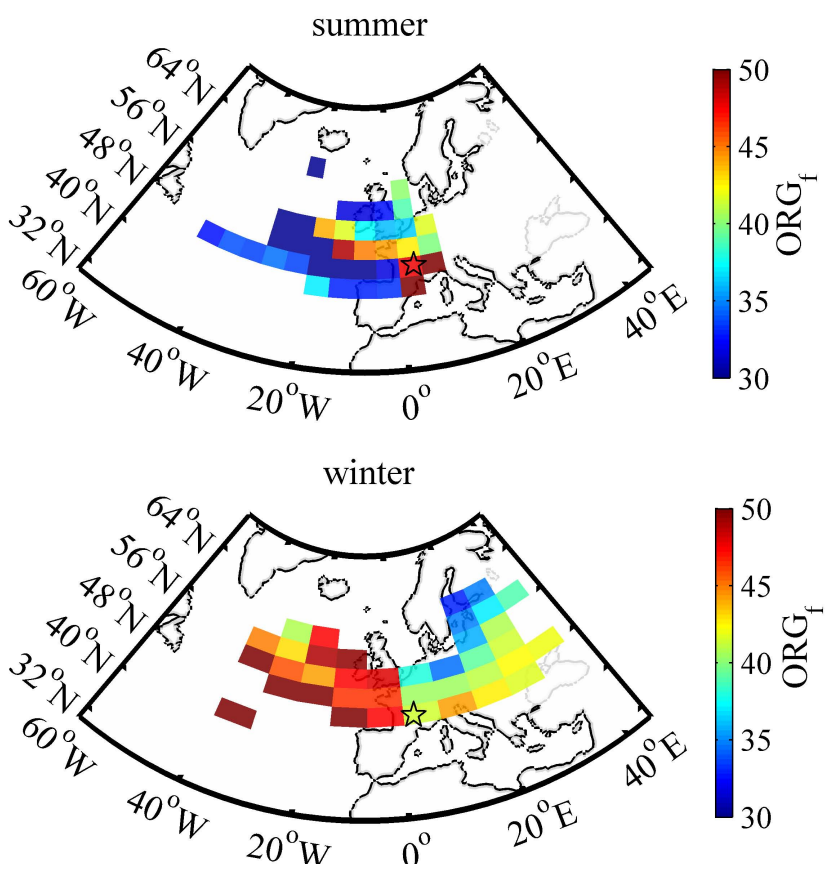

Fig. 9. Aerosol organic mass fraction from AMS with the air mass origin during summer (up) and winter (down) for the periods of simultanious $\mathrm{CCN}$ measurements. The star marks the location of the measurement site. For details of the calculations, see Sect. 3.3: aerosol CCN properties by air masses.

Freney et al. (2011) do not present marine air masses during winter period. Organics were present in high mass fractions also in Southern European air masses and this fraction shows a decreasing tendency towards Northern Europe. This could be explained by climatic conditions and snow cover in northern parts of Europe, further suppressing biogenic activities and release of organics from vegetation sources. The relatively high organic mass fraction of around 0.4 in Southern European air masses, coinciding with the highest observed $\kappa$ values, further indicates either very aged organic aerosol or surface active organics, where depression of aerosol particle surface tension could explain the observed high CCN activity (McFiggans et al., 2006). During summer, the highest fractions of organics are in contrast detected in Southern European air masses and the lowest in marine air masses.

It seems that the observed variability of aerosol $\kappa$ parameter can be qualitatively explained by the variations in aerosol organic mass fraction. However, another question is how well we can predict the aerosol organic fraction and the properties of these organics. Even if our $\kappa$ values fit to the global $\kappa$ range, the results also highlight the importance of temporal variability in particle chemistry which further affects aerosol cloud activation.

The observed elevated concentrations of organics, decreasing the aerosol $\kappa$ parameter in marine air masses during winter is intriguing. The presence of high quantities of organics in marine aerosol has also been reported by previous stud-
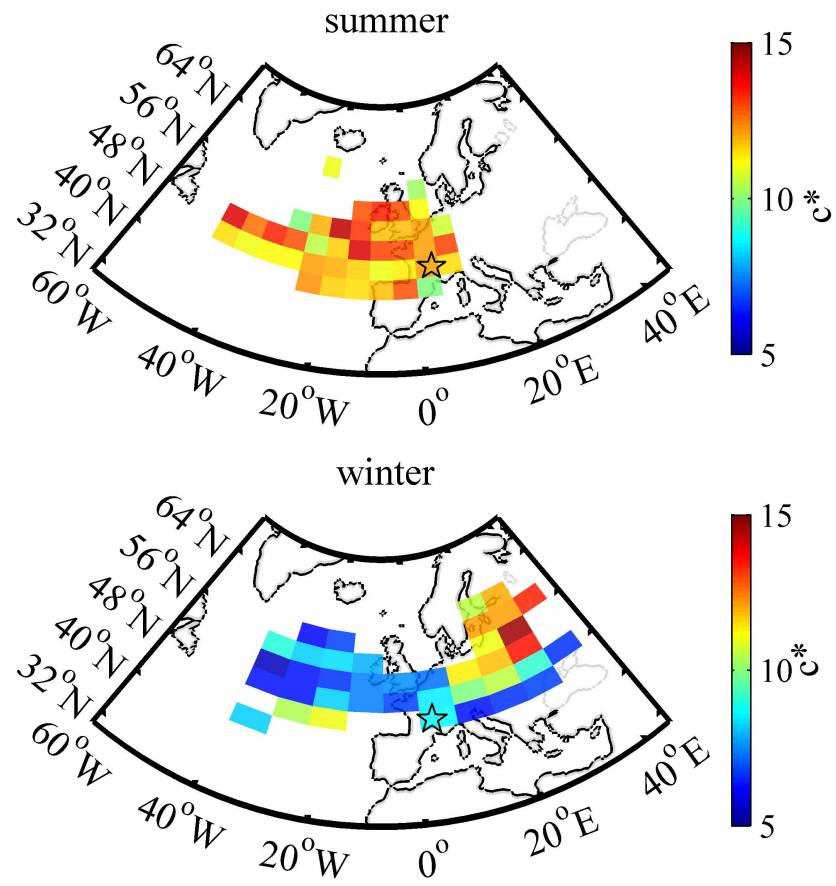

Fig. 10. Aerosol homogeneity (internal/external mixture) parameter $c^{*}$ value with the air mass origin during summer (up) and winter (down). The star marks the location of the measurement site. For details of the calculations, see Sect. 3.3: aerosol CCN properties by air masses.

ies (O'Dowd et al., 2004; Chang et al., 2011; Ovadnevaite et al., 2011a). However, the marine organic fraction seasonal and/or spatial variability, and furthermore, the hygroscopic or $\mathrm{CCN}$ properties of these organics, also subject to aging, are not truly understood. Consequently, the reported results are highly disperse (Allan et al., 2008; Asmi et al., 2010; Martin et al., 2011; Ovadnevaite et al., 2011b).

Finally, the aerosol mixing state within the measured air masses was studied by using the steepness of the fitting slope ( $c^{*}$, Eq. 3) as an indication of aerosol mixture homogeneity. During summer this parameter did not show significant variations with air masses, and values of $c^{*}$ of around 10 to 15 were constantly seen. For comparison, the value of $c^{*}$ obtained for our calibration aerosols of ammonium sulphate and sodium chloride varied within 20 to 30 . This indicates that the atmospheric aerosol during summer was not purely of uniform composition but rather the external mixing state remain relatively constant. During winter, $c^{*}$ varied from about 5 up to about 15 , showing the lowest values (i.e. more external mixture) in marine and Southern European air masses, where the fraction of the organics was the highest. The mainly inorganic Northern European aerosol was instead closer to an internal mixture. With only the limited amount of data available, it seems unfair to draw too far-reaching conclusions on the differences in aerosol mixing state between the seasons. However, the results seem to indicate that 
summer aerosol is better mixed, regardless of the aerosol organic fraction, than aerosol during winter. A plausible explanation for this is different origins of the organics affecting their mixing and aging time-scales. Cubison et al. (2008) suggested a time scale on the order of 1 to 2 days for the aerosol near pollution sources to become internally mixed. It is possible that the winter continental aerosol is exposed to several anthropogenic sources on the way leading to more external state observed at our site. For marine aerosol, the externally mixed nature might be caused by aerosol transport over the continent, mixing continental air to marine air before arriving at the site. During winter, the high elevation of the site should additionally be kept in mind, because this enables mixing of lower tropospheric air with more aged free tropospheric aerosol.

\subsection{Organic aerosol fraction}

The properties of organic aerosol can be highly variable. This variation can explain a part of the $\kappa$ variation observed, and therefore we had a closer look at the aerosol organic fraction measured with the AMS. The AMS measured aerosol mass fractions were converted to aerosol volume fractions using densities 1.3, 1.77 and 1.8 for organic, inorganic and black carbon (BC) fractions of aerosols. BC was assumed insoluble $(\kappa=0)$ and inorganic fraction soluble with $\kappa$ of 0.61 (based on CCNc calibrations with ammonium sulphate). Using the simple ZSR mixing rule (Stokes and Robinson, 1966), the only unknown remains the $\kappa$ of aerosol organic fraction, $\kappa_{\mathrm{ORG}}$, which is then

$\kappa_{\mathrm{ORG}}=\frac{\kappa-0.61 \cdot \mathrm{V}_{\mathrm{INORG}}-0.0 \cdot \mathrm{V}_{\mathrm{BC}}}{\mathrm{V}_{\mathrm{ORG}}}$

where $V_{\text {ORG }}$ is the volume fraction of organics, $V_{\text {INORG }}$ that of inorganics, and $\mathrm{V}_{\mathrm{BC}}$ that of black carbon.

This approach, leading to an average value of $\kappa_{\mathrm{ORG}}$ of $0.03 \pm 0.20$ in summer and $0.28 \pm 0.23$ in winter, was tested with AMS results. Positive matrix factorisation (PMF) was used to separate the organic mass spectra into groups of less volatile oxygenated organic aerosol (LV-OOA) and semivolatile oxygenated organic aerosol (SV-OOA). During summer campaign, the LV-OOA species had its characteristic peaks with highest contribution from $\mathrm{m} / z 44\left(\mathrm{CO}_{2+}\right)$. The SV-OOA component had high contributions from $\mathrm{m} / z 43$ as well as from $m / z 55,57$, and 91, characteristic of less aged organic aerosol. The temporal evolution of the SV-OOA and LV-OOA were similar as is characteristic of the pdD site (Freney et al., 2011). The LV-OOA, contributing approximately $75 \%$ to the measured organic mass concentrations has similar mass spectra to an oxidised organic aerosol measured in previous campaigns (Ulbrich et al., 2009; Lanz et al., 2010). The SV-OOA made up the remaining $25 \%$ of the total organic aerosol and has similar mass spectral profiles to SV-OOA measured at other research sites ( $\mathrm{Ng}$ et al., 2010). During winter the PMF analysis of the organic aerosol par-

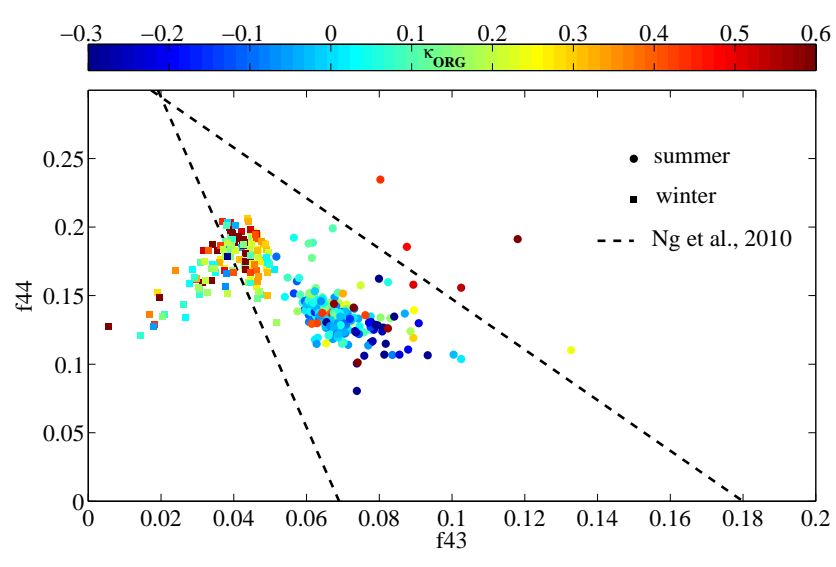

Fig. 11. Organic aerosol $\mathrm{m} / \mathrm{z} 44$ ratio to total organics (f44) as a function of $\mathrm{m} / \mathrm{z}, 43$ ratio to total organics (f43). Tringle (dashed lines) are taken from $\mathrm{Ng}$ et al. (2010). Round symbols are used for summer and squared for winter. Data are averaged by 120-min for each point. The colour shows the calculated organic aerosol $\kappa$, based on AMS and CCNc measurements.

ticles resolved two oxygenated organics but no primary or hydrocarbon organic aerosol. This is in agreement with other measurements made at the $\mathrm{pdD}$ site illustrating that the $\mathrm{pdD}$ site is not often advected by fresh emissions.

When the ratio of $\mathrm{m} / \mathrm{z} 44$ fraction of organics $(f 44)$ to $\mathrm{m} / \mathrm{z}, 43$ fraction of organics (f43) is depicted, most of the atmospheric measurements have been seen to fit within a triangle, defined by $\mathrm{Ng}$ et al. (2010), such as Kulmala et al. (2011). We plotted this triangle on top of our measurement points and coloured our data with estimated $\kappa_{\mathrm{ORG}}$ (Fig. 11). It seems that the points measured during summer fall to a lower level of the triangle, as an indication of higher fractions of SV-OOA, while the points measured during winter gather on the upper left side of the triangle, thereby indicating mainly LV-OOA. Raatikainen et al. (2010) showed that SV-OOA are rather connected to local emissions and LV-OOA fraction to long-range transported organics. Further the division in leftright axis indicates more biogenic sources during summer with respect to possibly biomass burning sources dominating during winter. An interesting period during winter is the beginning of campaign, when marine air masses with small values of $\kappa$ and high mass fractions of organics were observed. In the triangle, this period is represented by the points scattered on the left side of the triangle, showing the smallest $\kappa_{\mathrm{ORG}}$ values detected. It is clearly separate from rest of the winter data, where high $\kappa_{\mathrm{ORG}}$ values from long-distance sources seem to dominate. It is also noteworthy that during summer the approach used for calculating $\kappa_{\mathrm{ORG}}$ leads often to negative values. This can be seen as an indication of fresh organics actually inhibiting the particle $\mathrm{CCN}$ activation due to their surface effects, but can as well be solely the variation within uncertainties of the method for calculating $\kappa_{\mathrm{ORG}}$. One evident uncertainty for example comes from the fixed value of inorganic $\kappa$. Testing the sensitivity of average $\kappa_{\mathrm{ORG}}$ for 
$30 \%$ variability in $\kappa_{\text {INORG }}$, led to roungly \pm 0.2 variability in absolute value of $\kappa_{\mathrm{ORG}} \cdot \kappa_{\mathrm{ORG}}$ was also seen to have a positive correlation with organic mass fraction ( $\mathrm{p}$-value 0.007 ).

\subsection{CCN closure}

While the aerosol organic volume fraction varies within the limits of about 0.3 to 0.7 , we can study the change of total aerosol $\kappa$ (at SS $0.24 \%$ ) as a function of this fraction. Further, extrapolating up to an organic fraction of 1.0, gives an average approximation of the $\kappa$ of organic aerosol fraction. For summer this results in $\kappa_{\mathrm{ORG}}$ of 0.11 , while in winter this results in a higher $\kappa_{\mathrm{ORG}}$ of 0.26 . Considering the $\mathrm{f} 44$ ratio (Fig. 11), together with measured total aerosol $\kappa$, it is clear that the organic aerosol during winter is more aged than during summer and, consequently, the approximated $\kappa_{\mathrm{ORG}}$ values of 0.11 and 0.26 for summer and winter, respectively, seem reasonably well justified. Using similar method, Gunthe et al. (2009) found $\kappa_{\mathrm{ORG}}$ of 0.1 in tropical rainforest. However, comparing these results with average $\kappa_{\mathrm{ORG}}$ values of 0.03 and 0.28 for summer and winter, respectively, we may notice that this method tends to give more weight to the highest organic fractions.

The estimated $\kappa_{\mathrm{ORG}}$ values of 0.11 and 0.26 were used to obtain a closure between chemistry based $\mathrm{CCN}_{0.24}$ and measured $\mathrm{CCN}_{0.24}$ concentrations. $\mathrm{CCN}$ concentrations based on AMS bulk chemistry were calculated based on $\kappa$-Köhler (Eq. 4). Thus, aerosol chemistry derived $\kappa$ was first derived based on an estimated value of $\kappa_{\mathrm{ORG}}$, and using Eq. (5) to calculate aerosol $\kappa$. Then, these values were converted to activation diameters (Eq. 4) at SS $0.24 \%$. Finally, the DMPS measured size distributions were integrated for the size range of activation. In this approach, the aerosol is considered as fully internally mixed, and a sole diameter represents the activation size.

It appears that the AMS derived $\mathrm{CCN}$ concentrations are in good agreement with those measured by CCNc (Fig. 12). Yet, a positive bias of $5 \%$ and $2 \%$ in winter and summer, respectively, was obtained and the data measured during winter $\left(R^{2}=0.99\right)$ were less scattered than that in summer $\left(R^{2}=0.88\right)$. A likely reason for the slight overprediction is that aerosol organic fraction in bulk chemistry is underestimated with respect to the organic fraction in aerosols at sizes of CCN activation. This is supported with summer measurements at two different supersaturations, where the $\kappa$ values calculated for higher supersaturation of $0.51 \%$ remained lower than those calculated for SS $0.24 \%$ (Fig. 13). In particular, when the AMS measured the lowest organic volume fractions, the $\kappa_{0.51}$ remained well below $\kappa_{0.24}$, indicating that in smaller sizes larger fractions of organics were still present and/or they were less hygroscopic, for example, due to shorter aging time. The average $\kappa_{0.51}$ of 0.22 and $\kappa_{0.24}$ of 0.29 correspond to activation sizes of $63 \mathrm{~nm}$ and $95 \mathrm{~nm}$, thus representing in principle Aitken and accumulation mode aerosol activation properties.

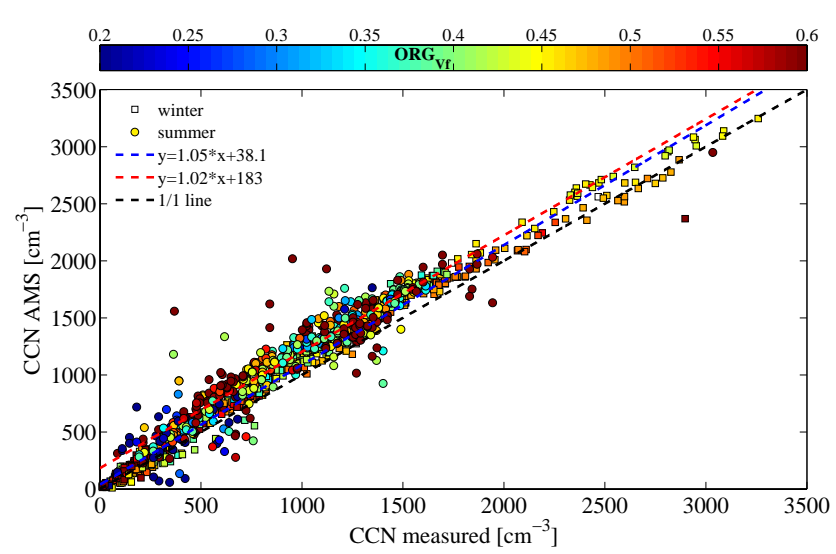

Fig. 12. Aerosol $\mathrm{CCN}_{0.24}$ number concentration estimated based on aerosol chemistry from AMS (y-axis) as a function of that measured with the $\mathrm{CCN}$ counter ( $\mathrm{x}$-axis) during winter (squared points) and summer (round points). Aerosol organic fraction $\kappa_{\mathrm{ORG}}$ was assumed 0.26 during winter and 0.11 during summer. Linear fittings for winter (blue line) and for summer (red line) are also presented along with $1 / 1$ line (black). The $R^{2}$ values of fittings were 0.99 and 0.88 , respectively for winter and summer.

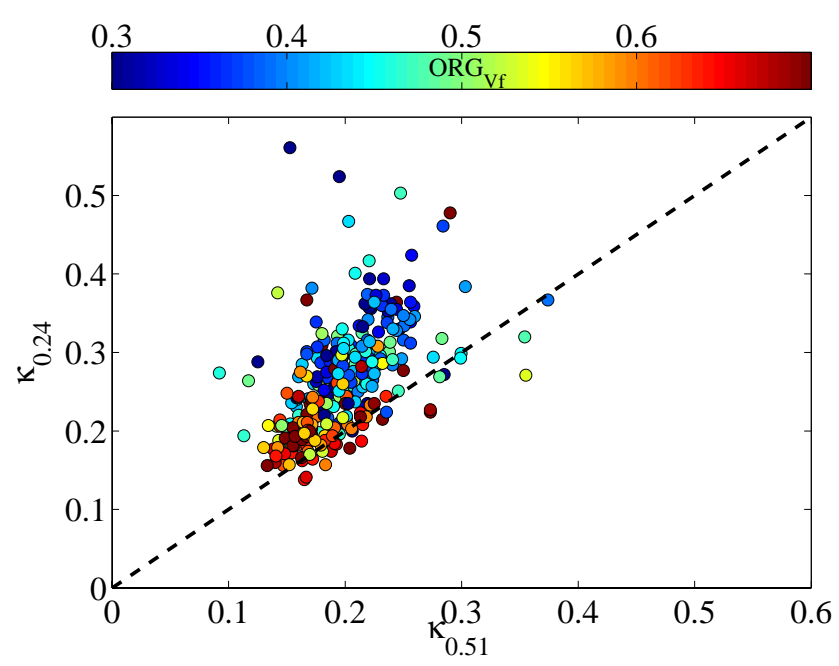

Fig. 13. Measured aerosol CCN $\kappa$ at SS $0.24 \%$ (y-axis) and at SS $0.51 \%$ (x-axis), taken from the consecutive $\mathrm{CCN}$ measurements at the two SS, as a function of the organic volume fraction (colour scale) derived from the AMS total aerosol composition during summer period.

An increase of the value of aerosol $\kappa$-parameter with size has also been seen by Gunthe et al. (2009); Cerully et al. (2011); Fors et al. (2011); Martin et al. (2011) and even in Antarctica (Asmi et al., 2010). The size dependency of the aerosol organic fraction depends however on the measurement site, and in some cases, also an increase of hygroscopicity with decreasing size has been reported (Bougiatioti et al., 2011). This size dependency has also previosly been suggested to explain the differences observed in $\mathrm{CCN}$ 


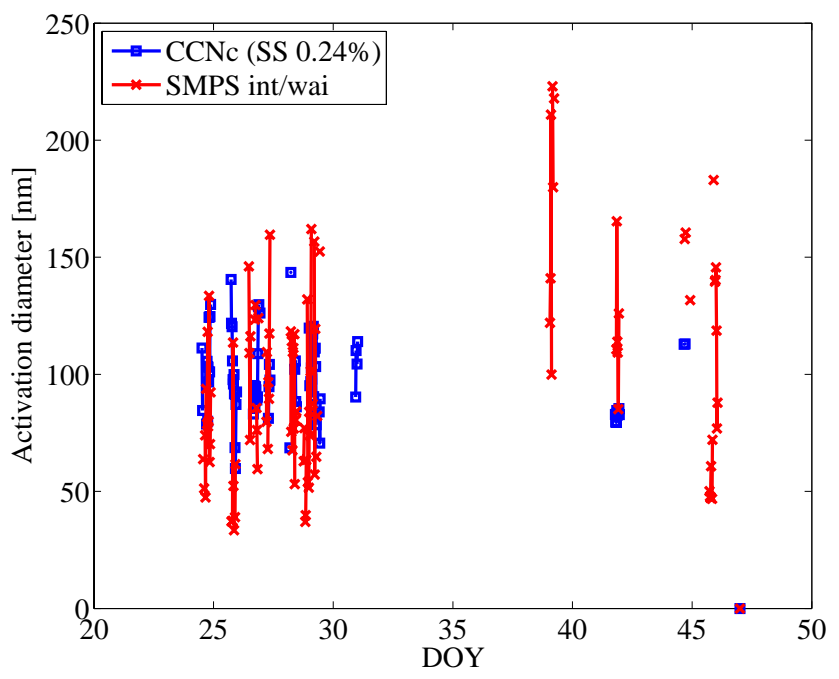

Fig. 14. Measured aerosol activation diameters during winter by CCN counter at SS $0.24 \%$ (blue squares) and by swithing between WAI and interstitial inlet using the SMPS (red crosses).

closures with bulk chemical information included (Cerully et al., 2011).

\subsection{Cloud droplet number concentration and cloud supersaturation}

In the last part of the analysis, we wish to connect our $\mathrm{CCN}$ measurements with actual particle in-cloud activation. In order to do this, the particle cloud activation diameters were calculated using the switching-SMPS system, where the activated fraction $\mathrm{Af}_{\mathrm{i}}$ in each SMPS channel was obtained as

$\mathrm{Af}_{i}=\frac{\mathrm{N}_{\mathrm{WAI}_{i}}-\mathrm{N}_{\mathrm{INT}_{i}}}{\mathrm{~N}_{\mathrm{WAI}_{i}}}$,

where $\mathrm{N}_{\mathrm{WAI}_{i}}$ is the number of particles measured in channel $i$ in whole air inlet (WAI), and $\mathrm{N}_{\mathrm{INT}_{i}}$ the corresponding particle number in interstitial inlet (INT). The concentrations were measured in 15 min turns in WAI and in INT, and average concentrations measured during these 15-min periods were compared. After this, sigmoidal fits (Eq. 3) were fitted to activated fraction versus diameter, as in the case of $\mathrm{CCNc}$ data.

In Fig. 14 an example of determined activation diameters is shown. Due to the sensitivity of the method to changes in size distribution during the 30-min measurement period, and due to noise caused by the low number concentrations, the scatter in data is evident. Part of the scatter might also be explained by the scatter in supersaturations experienced by the in-cloud particles. Nevertheless, the results should be interpreted keeping in mind the large uncertainties associated with the method. What can already be noticed based on Fig. 14 is that the chosen principal supersaturation of $0.24 \%$ corresponds in most cases well to the in-cloud supersaturation, as the activation diameters measured in-cloud and by the $\mathrm{CCNc}$, are of the same order of magnitude.

The most straightforward comparison can be done simply by comparing the measured accumulation mode $(>100 \mathrm{~nm})$ number concentrations with the corresponding cloud droplet number concentrations (CDNC), obtained by comparing the INT and WAI number concentrations. Previous studies, made mainly for marine aerosols, have found quadratic dependence, such that with increasing number concentration the fraction of CDNC gets smaller (Twohy, 2005; Lihavainen et al., 2008). This is also indicated by our results (Fig. 15). In contrast, within the uncertainties included, the dependence of CDNC on $\kappa$ parameter is not evident. We believe, however, that changes in cloud liquid water content (LWC) can, in addition to aerosol $\kappa$, explain a major fraction of the scatter. Unfortunately, LWC measurements were not available during campaigns. Figure 15 shows also the obvious resemblance between the accumulation mode number concentration $\left(\mathrm{CN}_{>100 \mathrm{~nm}}\right)$ and $\mathrm{CCN}_{0.24}$ concentration. The main result is however plotted as a function of $\mathrm{CN}_{>100 \mathrm{~nm}}$ in order to be able to compare with previous studies.

Finally, the in-cloud supersaturation can be determined when the available information: the real activation diameter of the in-cloud aerosol (Eq. 6) and the $\kappa$ from $\mathrm{CCN}_{0.24}$, are combined in the $\kappa$-Köhler theory (Eq. 4). Our results indeed suggest decrease in cloud supersaturation with increasing accumulation mode aerosol concentration (Fig. 16). With the smallest $\mathrm{CN}_{>100 \mathrm{~nm}}$ values of below $100 \mathrm{~cm}^{-3}$, cloud SS values between 0.2 and 0.6 are obtained while when $\mathrm{CN}_{>} 100 \mathrm{~nm}$ is over $200 \mathrm{~cm}^{-3}$, SS remains in range 0.1 to 0.3 . This correlation suggests the aerosol particles are important for cloud supersaturation profiles and in particular in environments of low initial particle numbers.

The study by Anttila et al. (2009) found cloud supersaturations on the order of 0.18 to $0.26 \%$ for low-level clouds in Northern Finland in conditions of total aerosol concentrations reaching from 200 to $2000 \mathrm{~cm}^{-3}$, which is in line with our results. By contrast, their study did not find an effect of changing aerosol concentration to resulting cloud supersaturation. Roberts et al. (2006) suggested an in-cloud supersaturation on the order of $0.3 \%$ over the Eastern Pacific Ocean based on minima between Aitken and accumulation modes. Hegg et al. (2009) obtained a SS range from 0.2 to 0.3 for clouds over the Californian coast. One of the advantages in our study was the vast range of $\mathrm{CN}_{>100 \mathrm{~nm}}$, which allowed for determining the effect of aerosols on in-cloud SS. To further verify our results, more work, especially in regions where aerosol number concentrations are low, is needed. This should, in addition to CCN measurements and in-cloud activated aerosol fractions, include a more detailed characterisation of cloud properties and local meteorology in order to offer more quantitative estimates of aerosol effects on different types of clouds. 


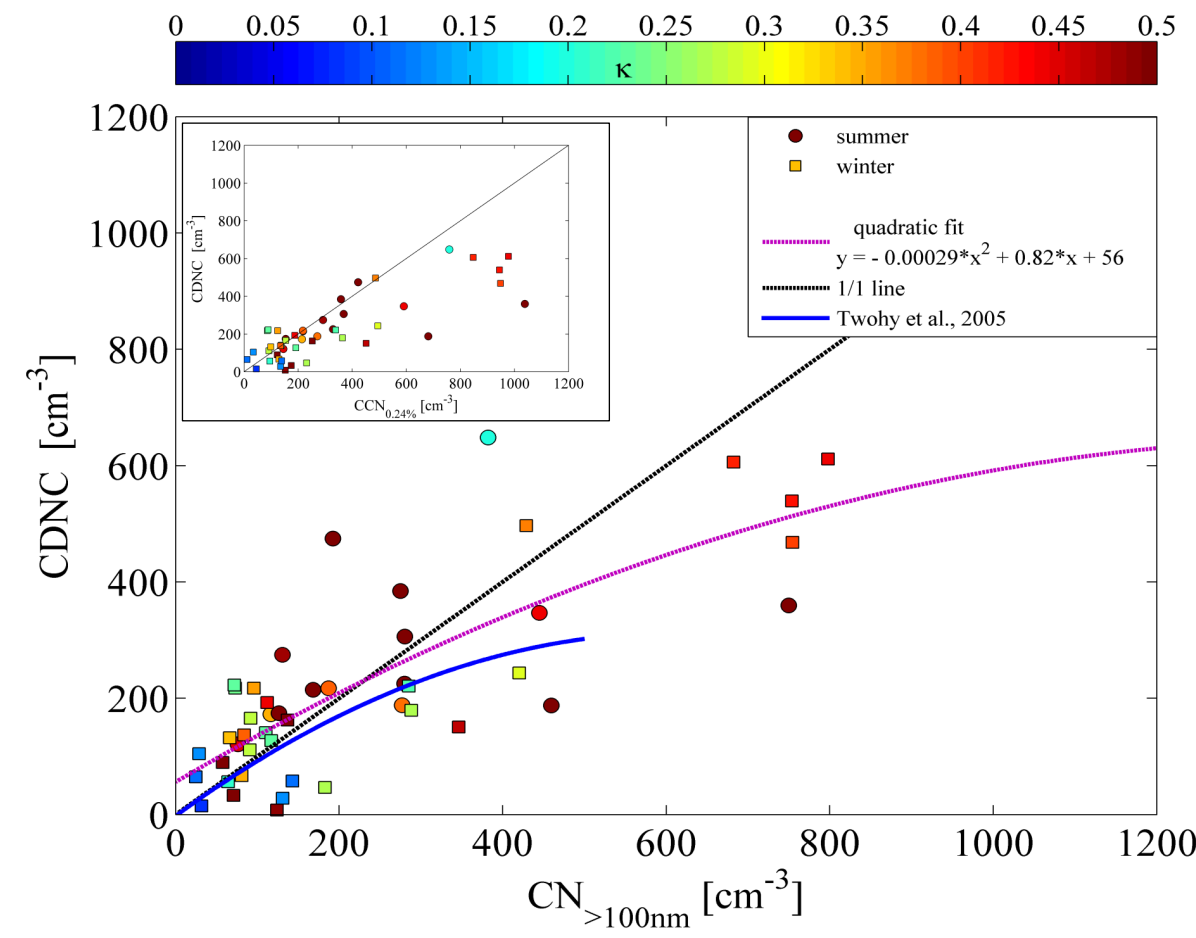

Fig. 15. Cloud droplet number concentration (y-axis) as a function of the aerosol accumulation mode number concentration (x-axis). Rounded symbols mark points measured during summer and squered those during winter. Colour of the points shows CCNc measured aerosol $\kappa$ parameter. Small picture on the left upper corner shows the $\mathrm{CDNC}$ as a function of the $\mathrm{CCN}_{0.24}$ concentration, and is shown here to note that typically $\mathrm{CN}_{>100 \mathrm{~nm}}$ represents well the aerosol $\mathrm{CCN}_{0.24}$ concentration at our measurement site.

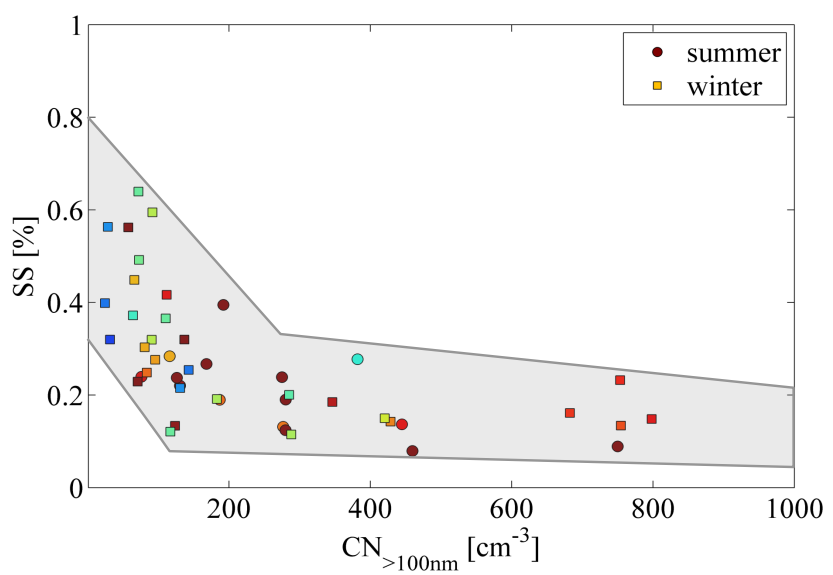

Fig. 16. Cloud maximum supersaturation (y-axis) as a function of the aerosol accumulation mode number concentration (x-axis). Gray shaded area is presented to highlight the region where the points fall into. Rounded symbols mark points measured during summer and squered those during winter. Colour of the points shows CCNc measured aerosol $\kappa$-parameter.

\section{Conclusions}

We measured size-segregated cloud condensation nuclei (CCN) concentrations at two supersaturations (SS) of $0.24 \%$ and $0.51 \%$ at a puy-de-Dôme measurement station in Central France. These were analysed with respect to air mass origin, aerosol in-situ chemistry, aerosol number size distributions and local meteorology. Obtained results were also compared with real activated aerosol profiles, measured using two inlet systems.

The results show that the aerosol CCN activity at puy-deDôme fits into the prevailing picture of global aerosol activation properties. The obtained range of a hygroscopicity parameter $\kappa$ was $0.29 \pm 0.13$ in summer and $0.43 \pm 0.19$ in winter, when calculated using SS of $0.24 \%$, thereby representing an accumulation mode aerosol at our site. When $\kappa$ was calculated using SS of $0.51 \%$ in summer, which is more representative for Aitken mode aerosol, a lower value of $0.22 \pm 0.07$ was obtained. These values are within the previously suggested global continental $\kappa$ of $0.27 \pm 0.21$.

The absolute CCN number concentration in summer ranged from about 200 up to $2000 \mathrm{~cm}^{-3}$ and during winter from 50 up to $3000 \mathrm{~cm}^{-3}$. The variability in CCN number could be explained by both particle chemistry and size distribution variability, and the highest $\mathrm{CCN}$ concentrations were measured in continental air masses both during winter and summer. The $\mathrm{CCN}$ to $\mathrm{CN}$ ratios were on average higher during winter, stemming from aged aerosol properties with a strong accumulation mode concentration. However, the highest $\mathrm{CCN}$ to $\mathrm{CN}$ ratios coincided with the highest observed $\kappa$ 
values, thereby highlighting the importance of chemistry in aerosol activation.

In summer, the continental European aerosols contained the highest fractions of organics, and consequently, showed also the lowest $\kappa$ values. In winter, the lowest $\kappa$ values were surprisingly observed in marine air masses, again accompanied by the highest organic mass fractions of up to $60 \%$ measured by the AMS. In contrast, the continental European air masses contained less organics during winter, likely explained by suppression of biogenic activities. The properties of aerosol organics, and likely also their sources, were also different between summer and winter. During summer, less aged organics possibly from biogenic sources were measured during the whole period of the campaign. In contrast, the organics in winter had higher $\mathrm{f} 44$ ratio, suggesting more aged organics. This seemed to be the principal reason also for the higher overall aerosol $\kappa$ value during winter, and provides evidence of the important role of organics in understanding aerosol $\mathrm{CCN}$ activation.

A closure study using AMS-derived bulk chemistry and measured CCN number concentration showed a good agreement. However, using solely chemical composition data a modest overestimation with a bias of $5 \%$ in winter and $2 \%$ in summer in CCN numbers was obtained. This overestimation is likely explained by the size range dependent differences in particle chemical composition as well as by the effects of particle external mixing state, since only a bulk derived AMS chemical composition and an assumption of internal mixture was used for the closure. Nevertheless, in predicting the $\mathrm{CCN}$ numbers an error made by these simplifying assumptions seems to be small.

The use of the two inlet system allowed us to compare our potential cloud active concentrations $(\mathrm{CCN})$ with real observed activated particles (CDNC) inside a cloud. It was shown that the chosen supersaturation of $0.24 \%$ represents well the actual in-cloud supersaturation at our site when the accumulation mode concentration is $>200 \mathrm{~cm}^{-3}$. In contrast, when the initial accumulation mode concentration is low, the clouds seem to obtain higher supersaturations. Incloud SS values up to 0.65 were determined based on experimental data. It is though emphasized that due to several experimental and modelling uncertainties, these are more qualitative than quantitative results. Nevertheless, they provide evidence of the important effects of aerosols on obtained cloud supersaturation profiles, which are likely to be important especially in environments of low initial aerosol concentrations.

Acknowledgements. Authors greatfully acknowledge the support from Marie-Curie IRG project ACI-AMS and the postdoctoral fellowship funding from AXA Research Fund. Authors also wish to acknowledge the funding from FEDER and Conseil régional d'Auvergne as well as the financial support of ACTRIS.

Edited by: V.-M. Kerminen

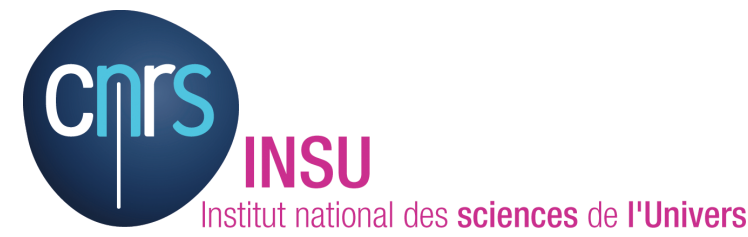

The publication of this article is financed by CNRS-INSU.

\section{References}

Anttila, T., Vaattovaara, P., Komppula, M., Hyvärinen, A.-P., Lihavainen, H., Kerminen, V.-M., and Laaksonen, A.: Sizedependent activation of aerosols into cloud droplets at a subarctic background site during the second Pallas Cloud Experiment (2nd PaCE): method development and data evaluation, Atmos. Chem. Phys., 9, 4841-4854, doi:10.5194/acp-9-4841-2009, 2009.

Albrecht, B. A.: Aerosols, cloud microphysics, and fractional cloudiness, Science, 245, 1227-1230, 1989.

Allan, J. D., Delia, A., Coe, H., Bower, K., Alfarra, M., Jimenez, J., Middlebrook, A., Drewnick, F., Onasch, T., Canagaratna, M., Jayne, J., and Worsnop, D.: A generalised method for the extraction of chemically resolved mass spectra from aerodyne aerosol mass spectrometer data, J. Aerosol Sci., 35, 909-922, doi:10.1016/j.jaerosci.2004.02.007, 2004.

Allan, J. D., Baumgardner, D., Raga, G. B., Mayol-Bracero, O. L., Morales-García, F., García-García, F., Montero-Martínez, G., Borrmann, S., Schneider, J., Mertes, S., Walter, S., Gysel, M., Dusek, U., Frank, G. P., and Krämer, M.: Clouds and aerosols in Puerto Rico - a new evaluation, Atmos. Chem. Phys., 8, 12931309, doi:10.5194/acp-8-1293-2008, 2008.

Andreae, M. O. and Rosenfeld, D.: Aerosol-cloud-precipitation interactions. Part 1: The nature and sources of cloud-active aerosols, Earth-Sci. Rev., 89, 13-41, 2008.

Asa-Awuku, A., Moore, R. H., Nenes, A., Bahreini, R., Holloway, J. S., Brock, C. A., Middlebrook, A. M., Ryerson, T., Jimenez, J., DeCarlo, P., Hecobian, A., Weber, R. Stickel, R., Tanner, D. J., and Huey, L. G: Airborne cloud condensation nuclei measurements during the 2006 Texas Air Quality Study, J. Geophys. Res., 116, D11201, doi:10.1029/2010JD014874, 2011.

Asmi, E., Frey, A., Virkkula, A., Ehn, M., Manninen, H. E., Timonen, H., Tolonen-Kivimäki, O., Aurela, M., Hillamo, R., and Kulmala, M.: Hygroscopicity and chemical composition of Antarctic sub-micrometre aerosol particles and observations of new particle formation, Atmos. Chem. Phys., 10, 4253-4271, doi:10.5194/acp-10-4253-2010, 2010.

Bougiatioti, A., Fountoukis, C., Kalivitis, N., Pandis, S. N., Nenes, A., and Mihalopoulos, N.: Cloud condensation nuclei measurements in the marine boundary layer of the eastern Mediterranean: CCN closure and droplet growth kinetics, Atmos. Chem. Phys., 9, 7053-7066, doi:10.5194/acp-9-7053-2009, 2009.

Bougiatioti, A., Nenes, A., Fountoukis, C., Kalivitis, N., Pandis, S. N., and Mihalopoulos, N.: Size-resolved CCN distributions and activation kinetics of aged continental and marine aerosol, Atmos. Chem. Phys., 11, 8791-8808, doi:10.5194/acp11-8791-2011, 2011.

Canagaratna, M. R., Jayne, J. T., Jimenez, J. L., Allan, J. D., Alfarra, M. R., Zhang, Q., Onasch, T. B., Drewnick, F., Coe, H., 
Middlebrook, A., Delia, A., Williams, L. R., Trimborn, A. M., Northway, M. J., DeCarlo, P. F., Kolb, C. E., Davidovits, P., and Worsnop, D. R.: Chemical and microphysical characterization of ambient aerosols with the aerodyne aerosol mass spectrometer, Mass Spectrom. Rev., 26, 185-222, doi:10.1002/mas.20115, 2007.

Cerully, K. M., Raatikainen, T., Lance, S., Tkacik, D., Tiitta, P., Petäjä, T., Ehn, M., Kulmala, M., Worsnop, D. R., Laaksonen, A., Smith, J. N., and Nenes, A.: Aerosol hygroscopicity and CCN activation kinetics in a boreal forest environment during the 2007 EUCAARI campaign, Atmos. Chem. Phys., 11, 12369-12386, doi:10.5194/acp-11-12369-2011, 2011.

Chang, R. Y.-W., Slowik, J. G., Shantz, N. C., Vlasenko, A., Liggio, J., Sjostedt, S. J., Leaitch, W. R., and Abbatt, J. P. D.: The hygroscopicity parameter $(\kappa)$ of ambient organic aerosol at a field site subject to biogenic and anthropogenic influences: relationship to degree of aerosol oxidation, Atmos. Chem. Phys., 10, 5047-5064, doi:10.5194/acp-10-5047-2010, 2010.

Chang, R. Y.-W., Leck, C., Graus, M., Müller, M., Paatero, J., Burkhart, J. F., Stohl, A., Orr, L. H., Hayden, K., Li, S.M., Hansel, A., Tjernström, M., Leaitch, W. R., and Abbatt, J. P. D.: Aerosol composition and sources in the central Arctic Ocean during ASCOS, Atmos. Chem. Phys., 11, 1061910636, doi:10.5194/acp-11-10619-2011, 2011.

Cubison, M. J., Ervens, B., Feingold, G., Docherty, K. S., Ulbrich, I. M., Shields, L., Prather, K., Hering, S., and Jimenez, J. L.: The influence of chemical composition and mixing state of Los Angeles urban aerosol on CCN number and cloud properties, Atmos. Chem. Phys., 8, 5649-5667, doi:10.5194/acp8-5649-2008, 2008.

Drewnick, F., Hings, S., DeCarlo, P., Jayne, J., Gonin, M., Fuhrer, K., Weimer, S., Jimenez, J., Demerjian, K., Borrmann, S., and Worsnop, D.: A new time-of-flight aerosol mass spectrometer (ToF-AMS) - Instrument description and first field deployment, Aerosol Sci. Technol., 39, 637-658, doi:10.1080/02786820500182040, 2005.

Draxler, R. R. and Hess, G. D.: An overview of the HYSPLIT_4 modeling system of trajectories, dispersion, and deposition, Aust. Meteor. Mag., 47, 295-308, 1998.

Dusek, U., Frank, G. P., Hildebrandt, L., Curtius, J., Schneider, J., Walter, S., Chand, D., Drewnick, F., Hings, S., Jung, D., Borrmann, S., and Andreae, M. O.: Size matters more than chemistry for cloud-nucleating ability of aerosol particles, Science, 312, 1375-1376, 2006.

Ervens, B., Feingold, G., and Kreidenweis, S. M.:Influence of water-soluble organic carbon on cloud drop number concentration, J. Geophys. Res., 110, D18211, doi:10.1029/2004JD005634, 2005.

Fors, E. O., Swietlicki, E., Svenningsson, B., Kristensson, A., Frank, G. P., and Sporre, M.: Hygroscopic properties of the ambient aerosol in southern Sweden - a two year study, Atmos. Chem. Phys., 11, 8343-8361, doi:10.5194/acp-11-8343-2011, 2011.

Freney, E. J., Sellegri, K., Canonaco, F., Boulon, J., Hervo, M., Weigel, R., Pichon, J. M., Colomb, A., Prévôt, A. S. H., and Laj, P.: Seasonal variations in aerosol particle composition at the puy-de-Dôme research station in France, Atmos. Chem. Phys., 11, 13047-13059, doi:10.5194/acp-11-13047-2011, 2011.

Freney, E. J., Asmi, E., Hervo, M., Rose, C., Colomb, A., Picard, D., and Sellegri, K.: Particle chemical source apportionment and ver- tical mixing at the pdD station during winter 2012, in preparation, 2012.

Gill, P. S., Graedel, T. E., and Weschler, C. J.: Organic films on atmospheric aerosol particles, fog droplets, cloud droplets, raindrops, and snowflakes, Rev. Geophys., 21, 903-920, 1983.

Gunthe, S. S., King, S. M., Rose, D., Chen, Q., Roldin, P., Farmer, D. K., Jimenez, J. L., Artaxo, P., Andreae, M. O., Martin, S. T., and Pöschl, U.: Cloud condensation nuclei in pristine tropical rainforest air of Amazonia: size-resolved measurements and modeling of atmospheric aerosol composition and CCN activity, Atmos. Chem. Phys., 9, 7551-7575, doi:10.5194/acp-97551-2009, 2009.

Gunthe, S. S., Rose, D., Su, H., Garland, R. M., Achtert, P., Nowak, A., Wiedensohler, A., Kuwata, M., Takegawa, N., Kondo, Y., Hu, M., Shao, M., Zhu, T., Andreae, M. O., and Pöschl, U.: Cloud condensation nuclei (CCN) from fresh and aged air pollution in the megacity region of Beijing, Atmos. Chem. Phys., 11, 11023-11039, doi:10.5194/acp-1111023-2011, 2011.

Henning, S., Weingartner, E., Schmidt, S., Wendisch, M., Gäggeler, H. W., and Balternsperger, U.: Size-dependent aerosol activation at the high-alpine site Jungfraujoch ( $3580 \mathrm{~m}$ a.s.1.), Tellus B, 54, 82-95, doi:10.1034/j.1600-0889.2002.00299.x, 2002.

Hegg, D. A., Covert, D. S., Jonsson, H. H., and Woods, R.: Differentiating natural and anthropogenic cloud condensation nuclei in the California coastal zone, Tellus, 61B, 669-676, 2009.

Hudson, J.: Variability of the relationship between particle size and cloud-nucleating ability, Geophys. Res. Lett., 34, L08801, doi:10.1029/2006GL028850, 2007.

IPCC(AR4): Climate change 2007: Impacts, Adaptation and Vulnerability. Contribution of Working Group II to the Fourth Assessment Report of the Intergovernmental Panel on Climate Change, edited by: Parry, M. L., Canziani, O. F., Palutikof, J. P., van der Linden, P. J., and Hanson, C. E., Cambridge University Press, Cambridge, 2007.

Jimenez, J. L., Canagaratna, M. R., Donahue, N. M., Prévôt, A. S. H., Zhang, Q., Kroll, J. H., DeCarlo, P. F., Allan, J. D., Coe, H., Ng, N. L., Aiken, A. C., Docherty, K. S., Ulbrich, I. M., Grieshop, A. P., Robinson, A. L., Duplissy, J., Smith, J. D., Wilson, K. R., Lanz, V. A., Hueglin, C., Sun, Y. L., Tian, J., Laaksonen, A., Raatikainen, T., Rautiainen, J., Vaattovaara, P., Ehn, M., Kulmala, M., Tomlinson, J. M., Collins, D. R., Cubison, M. J., Dunlea, E. J., Huffman, J. A., Onasch, T. B., Alfarra, M. R., Williams, P. I., Bower, K., Kondo, Y., Schneider, J., Drewnick, F., Borrmann, S., Weimer, S., Demerjian, K., Salcedo, D., Cottrell, L., Griffin, R., Takami, A., Miyoshi, T., Hatakeyama, S., Shimono, A., Sun, J. Y., Zhang, Y. M., Dzepina, K., Kimmel, J. R., Sueper, D., Jayne, J. T., Herndon, S. C., Trimborn, A. M., Williams, L. R., Wood, E. C., Middlebrook, A. M., Kolb, C. E., Baltensperger, U., and Worsnop, D. R.: Evolution of organic aerosols in the atmosphere, Science, 326, 1525-1529, doi:10.1126/science.1180353, 2009.

Kammermann, L., Gysel, M., Weingartner, E., Herich, H., Cziczo, D. J., Holst, T., Svenningsson, B., Arneth, A., and Baltensperger, U.: Subarctic atmospheric aerosol composition: 3. Measured and modeled properties of cloud condensation nuclei, J. Geophys. Res., 115, D04202, 
doi:10.1029/2009JD012447, 2010.

Koehler, K. A., Kreidenweis, S. M., DeMott, P. J., Prenni, A. J., Carrico, C. M., Ervens, B., and Feingold, G.: Water activity and activation diameters from hygroscopicity data - Part II: Application to organic species, Atmos. Chem. Phys., 6, 795-809, doi:10.5194/acp-6-795-2006, 2006.

Köhler, H: The nucleus in and the growth of hygroscopic droplets, Trans. Faraday Soc., 1936, 32, 1152-1161, doi:10.1039/TF9363201152, 1936.

Kulmala, M., Asmi, A., Lappalainen, H. K., Baltensperger, U., Brenguier, J.-L., Facchini, M. C., Hansson, H.-C., Hov, Ø, O’Dowd, C. D., Pöschl, U., Wiedensohler, A., Boers, R., Boucher, O., de Leeuw, G., Denier van der Gon, H. A. C., Feichter, J., Krejci, R., Laj, P., Lihavainen, H., Lohmann, U., McFiggans, G., Mentel, T., Pilinis, C., Riipinen, I., Schulz, M., Stohl, A., Swietlicki, E., Vignati, E., Alves, C., Amann, M., Ammann, M., Arabas, S., Artaxo, P., Baars, H., Beddows, D. C. S., Bergström, R., Beukes, J. P., Bilde, M., Burkhart, J. F., Canonaco, F., Clegg, S. L., Coe, H., Crumeyrolle, S., D’Anna, B., Decesari, S., Gilardoni, S., Fischer, M., Fjaeraa, A. M., Fountoukis, C., George, C., Gomes, L., Halloran, P., Hamburger, T., Harrison, R. M., Herrmann, H., Hoffmann, T., Hoose, C., Hu, M., Hyvärinen, A., Hõrrak, U., Iinuma, Y., Iversen, T., Josipovic, M., Kanakidou, M., Kiendler-Scharr, A., Kirkevåg, A., Kiss, G., Klimont, Z., Kolmonen, P., Komppula, M., Kristjánsson, J.E., Laakso, L., Laaksonen, A., Labonnote, L., Lanz, V. A., Lehtinen, K. E. J., Rizzo, L. V., Makkonen, R., Manninen, H. E., McMeeking, G., Merikanto, J., Minikin, A., Mirme, S., Morgan, W. T., Nemitz, E., O’Donnell, D., Panwar, T. S., Pawlowska, H., Petzold, A., Pienaar, J. J., Pio, C., Plass-Duelmer, C., Prévôt, A. S. H., Pryor, S., Reddington, C. L., Roberts, G., Rosenfeld, D., Schwarz, J., Seland, Ø, Sellegri, K., Shen, X. J., Shiraiwa, M., Siebert, H., Sierau, B., Simpson, D., Sun, J. Y., Topping, D., Tunved, P., Vaattovaara, P., Vakkari, V., Veefkind, J. P., Visschedijk, A., Vuollekoski, H., Vuolo, R., Wehner, B., Wildt, J., Woodward, S., Worsnop, D. R., van Zadelhoff, G.-J., Zardini, A. A., Zhang, K., van Zyl, P. G., Kerminen, V.-M., S Carslaw, K., and Pandis, S. N.: General overview: European Integrated project on Aerosol Cloud Climate and Air Quality interactions (EUCAARI) - integrating aerosol research from nano to global scales, Atmos. Chem. Phys., 11, 1306113143, doi:10.5194/acp-11-13061-2011, 2011.

Kuwata, M., Kondo, Y., Miyazaki, Y., Komazaki, Y., Kim, J. H., Yum, S. S., Tanimoto, H., and Matsueda, H.: Cloud condensation nuclei activity at Jeju Island, Korea in spring 2005, Atmos. Chem. Phys., 8, 2933-2948, doi:10.5194/acp-8-2933-2008, 2008.

Lance, S., Nenes, A., and Rissman, T. A.: Chemical and dynamical effects on cloud droplet number: implications for estimates of the aerosol indirect effect, J. Geophys. Res., 109, D22208, doi:10.1029/2004JD004596, 2004.

Lance, S., Nenes, A., Mazzoleni, C., Dubey, M. K., Gates, H., Varutbangkul, V., Rissman, T. A., Murphy, S. M., Sorooshian, A., Flagan, R. C., Seinfeld, J. H., Feingold, G., and Jonsson, H. H.: Cloud condensation nuclei activity, closure, and droplet growth kinetics of Houston aerosol during the Gulf of Mexico Atmospheric Composition and Climate Study (GoMACCS), J. Geophys. Res., 114, D00F15, doi:10.1029/2008JD011699, 2009.
Lanz, V. A., Prévôt, A. S. H., Alfarra, M. R., Weimer, S., Mohr, C., DeCarlo, P. F., Gianini, M. F. D., Hueglin, C., Schneider, J., Favez, O., D’Anna, B., George, C., and Baltensperger, U.: Characterization of aerosol chemical composition with aerosol mass spectrometry in Central Europe: an overview, Atmos. Chem. Phys., 10, 10453-10471, doi:10.5194/acp-10-10453-2010, 2010.

Lihavainen, H., Kerminen, V.-M., Komppula, M., Hyvärinen, A.P., Laakia, J., Saarikoski, S., Makkonen, U., Kivekäs, N., Hillamo, R., Kulmala, M., and Viisanen, Y.: Measurements of the relation between aerosol properties and microphysics and chemistry of low level liquid water clouds in Northern Finland, Atmos. Chem. Phys., 8, 6925-6938, doi:10.5194/acp-8-6925-2008, 2008.

Martin, M., Chang, R. Y.-W., Sierau, B., Sjogren, S., Swietlicki, E., Abbatt, J. P. D., Leck, C., and Lohmann, U.: Cloud condensation nuclei closure study on summer arctic aerosol, Atmos. Chem. Phys., 11, 11335-11350, doi:10.5194/acp-11-11335-2011, 2011.

McFiggans, G., Artaxo, P., Baltensperger, U., Coe, H., Facchini, M. C., Feingold, G., Fuzzi, S., Gysel, M., Laaksonen, A., Lohmann, U., Mentel, T. F., Murphy, D. M., O’Dowd, C. D., Snider, J. R., and Weingartner, E.: The effect of physical and chemical aerosol properties on warm cloud droplet activation, Atmos. Chem. Phys., 6, 2593-2649, doi:10.5194/acp-6-25932006, 2006.

Medina, J., Nenes, A., Sotiropoulou, R.-E. P., Cottrell, L. D., Ziemba, L. D., Beckman, P. J., and Griffin, R. J.: Cloud condensation nuclei closure during the International Consortium for Atmospheric Research on Transport and Transformation 2004 campaign: effects of size-resolved composition, J. Geophys. Res., 112, D10S31, doi:10.1029/2006JD007588, 2007.

Middlebrook, A., Bahreini, R., Jimenez, J., and Canagaratna, M. R.: Evaluation of composition-dependent collection efficiencies for the aerodyne aerosol mass spectrometer using field data, Aerosol Sci. Technol., 46, 258-271, doi:10.1080/02786826.2011.620041, 2012.

Mochida, M., Nishita-Hara, C., Kitamori, Y., Aggarwal, S. G., Kawamura, K., Miura, K., and Takami, A.: Size segregated measurements of cloud condensation nucleus activity and hygroscopic growth for aerosols at Cape Hedo, Japan, in spring 2008, J. Geophys. Res., 115, D21207, doi:10.1029/2009JD013216, 2010.

Ng, N. L., Canagaratna, M. R., Zhang, Q., Jimenez, J. L., Tian, J., Ulbrich, I. M., Kroll, J. H., Docherty, K. S., Chhabra, P. S., Bahreini, R., Murphy, S. M., Seinfeld, J. H., Hildebrandt, L., Donahue, N. M., DeCarlo, P. F., Lanz, V. A., Prévôt, A. S. H., Dinar, E., Rudich, Y., and Worsnop, D. R.: Organic aerosol components observed in Northern Hemispheric datasets from Aerosol Mass Spectrometry, Atmos. Chem. Phys., 10, 46254641, doi:10.5194/acp-10-4625-2010, 2010.

O’Dowd, C. D., Facchini M. C., Cavalli F., Ceburnis, D., Mircea, M., Decesari, S., Fuzzi, S., Yoon, Y. J., and Putaud, J. P.: Biogenically driven organic contribution to marine aerosol, Nature, 431, 676-680, doi:10.1038/nature02959, 2004.

Ovadnevaite, J., Ceburnis, D., Martucci, G., Bialek, J., Monahan, C., Rinaldi, M., Facchini, M. C., Berresheim, H., Worsnop, D. R., and O'Dowd, C.: Primary marine organic aerosol: a dichotomy of low hygroscopicity and high CCN activity, Geophys. Res. Lett., 38, L21806, doi:10.1029/2011GL048869, 2011a. 
Ovadnevaite, J., O'Dowd, C., Dall'Osto, M., Ceburnis, D., Worsnop, D. R., and Berresheim, H.: Detecting high contributions of primary organic matter to marine aerosol: a case study, Geophys. Res. Lett., 38, L02807, doi:10.1029/2010GL046083, 2011 b.

Petters, M. D. and Kreidenweis, S. M.: A single parameter representation of hygroscopic growth and cloud condensation nucleus activity, Atmos. Chem. Phys., 7, 1961-1971, doi:10.5194/acp-71961-2007, 2007.

Planche, C., Wobrock, W., Flossmann, A. I., Tridon, F., Van Baelen, J., Pointin, Y., and Hagen, M.: The influence of aerosol particle number and hygroscopicity on the evolution of convective cloud systems and their precipitation: A numerical study based on the COPS observations on 12 August 2007, Atmos. Res., 98, 40-56. doi:10.1016/j.atmosres.2010.05.003, 2010.

Pringle, K. J., Tost, H., Pozzer, A., Pöschl, U., and Lelieveld, J.: Global distribution of the effective aerosol hygroscopicity parameter for CCN activation, Atmos. Chem. Phys., 10, 52415255, doi:10.5194/acp-10-5241-2010, 2010.

Quinn, P. K., Bates, T. S., Coffman, D. J., and Covert, D. S.: Influence of particle size and chemistry on the cloud nucleating properties of aerosols, Atmos. Chem. Phys., 8, 1029-1042, doi:10.5194/acp-8-1029-2008, 2008.

Raatikainen, T., Vaattovaara, P., Tiitta, P., Miettinen, P., Rautiainen, J., Ehn, M., Kulmala, M., Laaksonen, A., and Worsnop, D. R.: Physicochemical properties and origin of organic groups detected in boreal forest using an aerosol mass spectrometer, Atmos. Chem. Phys., 10, 2063-2077, doi:10.5194/acp-10-2063-2010, 2010.

Ramanathan, V., Crutzen, P. J., Kiehl, J. T., and Rosenfeld, D.: Aerosols, climate, and the hydrological cycle, Science, 294, 2119-2124, 2001.

Roberts, G. and Nenes, A.: Continuous-flow streamwise thermalgradient $\mathrm{CCN}$ chamber for airborne measurements, Aerosol Sci. Tech., 39, 206-221, 2005.

Roberts, G. C., Artaxo, P., Zhou, J., Swietlicki, E., and Andreae, M. O.: Sensitivity of CCN spectra on chemical and physical properties of aerosol: a case study from the Amazon Basin, J. Geophys. Res., 107, 8070, doi:10.1029/2001JD000583, 2002.

Roberts, G., Mauger, G., Hadley, O., and Ramanathan, V.: North American and Asian aerosols over the Eastern Pacific Ocean and their role in regulating cloud condensation nuclei, J. Geophys. Res., 111, D13205, doi:10.1029/2005JD006661, 2006.

Roberts, G. C., Day, D. A., Russell, L. M., Dunlea, E. J., Jimenez, J. L., Tomlinson, J. M., Collins, D. R., Shinozuka, Y., and Clarke, A. D.: Characterization of particle cloud droplet activity and composition in the free troposphere and the boundary layer during INTEX-B, Atmos. Chem. Phys., 10, 6627-6644, doi:10.5194/acp-10-6627-2010, 2010

Rogers, R. R.: An elementary parcel model with explicit condensation and supersaturation, Atmosphere, 13, 192-204, 1975.

Rose, D., Gunthe, S. S., Mikhailov, E., Frank, G. P., Dusek, U., Andreae, M. O., and Pöschl, U.: Calibration and measurement uncertainties of a continuous-flow cloud condensation nuclei counter (DMT-CCNC): CCN activation of ammonium sulfate and sodium chloride aerosol particles in theory and experiment, Atmos. Chem. Phys., 8, 1153-1179, doi:10.5194/acp-8-11532008,2008
Rosenfeld, D., Lohmann, U., Raga, G. B., O'Dowd, C. D., Kulmala, M., Fuzzi, S., Reissell, A., and Andreae, M. O.: Flood or drought: how do aerosols affect precipitation?, Science, 321, 1309-1313, doi:10.1126/science.1160606, 2008.

Saxena, P. and Hildemann, L. M.: Water-soluble organics in atmospheric particles: a critical review of the literature and application of thermodynamics to identify candidate compounds, J. Atmos. Chem., 24, 57-109, 1996.

Seinfeld, J. H. and Pandis, S. N.: Atmospheric Chemistry \& Physics: From Air Pollution to Climate Change, John Wiley \& Sons, New York, 1998.

Sihto, S.-L., Mikkilä, J., Vanhanen, J., Ehn, M., Liao, L., Lehtipalo, K., Aalto, P. P., Duplissy, J., Petäjä, T., Kerminen, V.M., Boy, M., and Kulmala, M.: Seasonal variation of CCN concentrations and aerosol activation properties in boreal forest, Atmos. Chem. Phys., 11, 13269-13285, doi:10.5194/acp-1113269-2011, 2011.

Sellegri, K., Laj, P., Peron, F., Dupuy, R., Legrand, M., Preunkert, S., Putaud, J.-P., Cachier, H., and Ghermandi, G.: Mass balance of free tropospheric aerosol at the Puy de Dôme (France) in winter, J. Geophys. Res., 108, 4333, doi:10.1029/2002JD002747, 2003a.

Sellegri, K., Laj, P., Dupuy, R., Legrand, M., Preunkert, S., and Putaud, J.-P.: Size-dependent scavenging efficiencies of multicomponent atmospheric aerosols in clouds, J. Geophys. Res., 108, 4334, doi:10.1029/2002JD002749, 2003b.

Stokes, R. H. and Robinson, R. A.: Interactions in aqueous nonelectrolyte solutions. I. Solute-solvent equilibria, J. Phys. Chem., 70, 2126-2130, 1966.

Twohy, C. H., Petters, M. D., Snider, J. R., Stevens, B., Tahnk, W., Wetzel, M., Russell, L., and Burnet, F.: Evaluation of the aerosol indirect effect in marine stratocumulus clouds: droplet number, size, liquid water path, and radiative impact, J. Geophys. Res., 110, D08203, doi:10.1029/2004JD005116, 2005.

Twomey, S.: The influence of pollution on the shortwave albedo of clouds, J. Atmos. Sci., 34, 1149-1152, 1977.

Ulbrich, I. M., Canagaratna, M. R., Zhang, Q., Worsnop, D. R., and Jimenez, J. L.: Interpretation of organic components from Positive Matrix Factorization of aerosol mass spectrometric data, Atmos. Chem. Phys., 9, 2891-2918, doi:10.5194/acp-9-2891-2009, 2009.

Venzac, H., Sellegri, K., Villani, P., Picard, D., and Laj, P.: Seasonal variation of aerosol size distributions in the free troposphere and residual layer at the puy de Dôme station, France, Atmos. Chem. Phys., 9, 1465-1478, doi:10.5194/acp-9-1465-2009, 2009.

Wiedensohler, A.: Die bipolare Diffusionsaufladung von Partikeln in chemisch trägen Reinstgasen, $\mathrm{PhD}$ thesis, University of Duisburg, Germany, 1989.

Young, K. C. and Warren, A. J.: A Reexamination of the derivation of the equilibrium supersaturation curve for soluble particles, J. Atmos. Sci., 49, 1138-1143, 1992.

Zhang, Q., Jimenez, J. L., Canagaratna, M. R., Allan, J. D., Coe, H., Ulbrich, I., Alfarra, M. R., Takami, A., Middlebrook, A. M., Sun, Y. L., Dzepina, K., Dunlea, E., Docherty, K., DeCarlo, P. F., Salcedo, D., Onasch, T., Jayne, J. T., Miyoshi, T., Shimono, A., Hatakeyama, S., Takegawa, N., Kondo, Y., Schneider, J., Drewnick, F., Weimer, S., Demerjian, K., Williams, P., Bower, K., Bahreini, R., Cottrell, L., Griffin, R. J., Rautiainen, J., Sun, J. Y., Zhang, Y. M., and 
Worsnop, D. R.: Ubiquity and dominance of oxygenated species in organic aerosols in anthropogenically-influenced Northern Hemisphere mid-latitudes, Geophys. Res. Lett., 34, L13801, doi:10.1029/2007GL029979, 2007. 